\title{
The Effects of Using Ground Water to Maintain Water Levels of Cedar Lake, Wisconsin
}
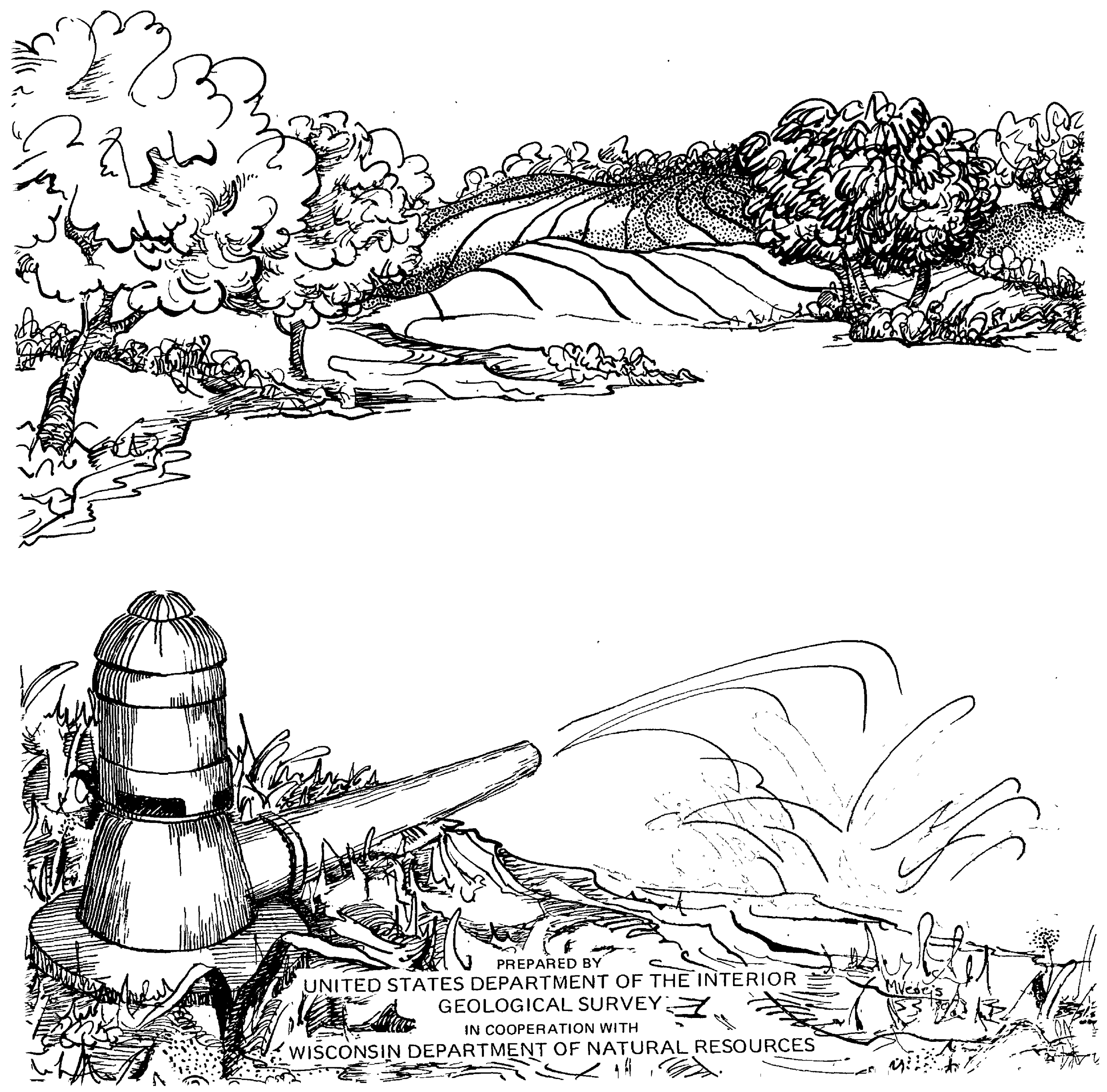
$50272-101$

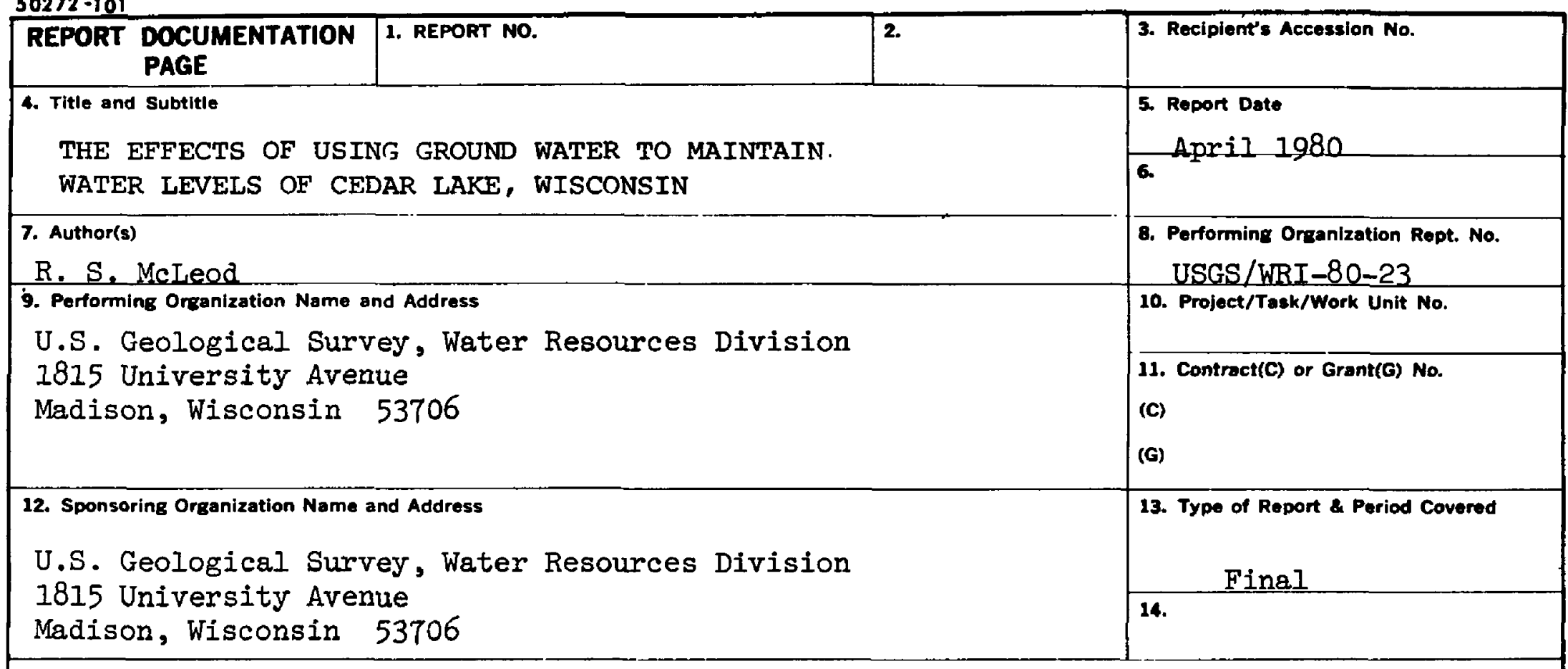

15. Supplementary Notes

Prepared in cooperation with the Wisconsin Department of Natural Resources

16. Abstract (Limit: 200 words)

Ground water was pumped into Cedar Lake, a kettle lake with no surface inlet or outlet, to evaluate the feasibility of maintaining water levels of lakes in the glaciated kettle moraine area of eastern Wisconsin. The lake is located in a local recharge area within a shallow aquifer system composed of unconsolidated glacial drift of Quaternary age and consolidated bedrock of Silurian age.

A water budget for Cedar Lake showed an average inflow of 45 inches per year, including precipitation on the lake surface (28 inches), ground-water seepage to the lake ( 2 inches), and overland flow ( 15 inches) to the lake. Outflow averaged approximately 49 inches per year, and consisted of evaporation ( 31 inches) from the lake surface and ground-water seepage from the lake (18 inches).

A volume of water equivalent to that needed to raise the lake level 47 inches was pumped from the shallow aquifer system into Cedar Lake between February $I$ and September 30, 1977. The water budget for the lake during this period indicated that approximately 90 percent of pumped water was either recycled from the lake to the well or otherwise lost as seepage from the lake.

17. Document Analysis a. Descriptors

Lakes, Hydrologic budget

b. Identlfiers/Open-Ended Terms

Wisconsin, Manitowoc County

c. COSATI Field/Group

18. Availobility Statement

No restriction on distribution

\begin{tabular}{|l|l|}
\hline $\begin{array}{l}\text { 19. Security Class (This Report) } \\
\text { UNCCLASSIFIED }\end{array}$ & $\begin{array}{l}\text { 21. No. of Pages } \\
41\end{array}$ \\
\hline $\begin{array}{l}\text { 20. Security Class (This Page) } \\
\text { UNCLASSIFIED }\end{array}$ & 22. Price \\
\hline
\end{tabular}




\section{The Effects of Using Ground Water to Maintain Water Levels of Cedar Lake, Wisconsin}

R. S. McLEOD

U. S. GEOLOGICAL SURVEY

Water Resources Investigations 80-23

Prepared in cooperation with the

Wisconsin Department of Natural Resources

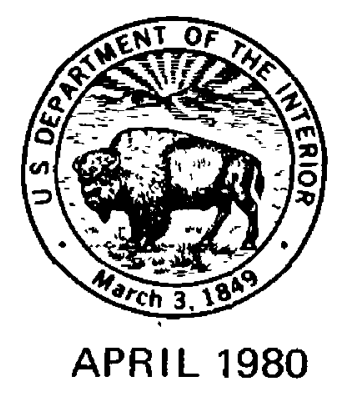




\title{
UNITED STATES DEPARTMENT OF THE INTERIOR
}

\author{
CECIL D. ANDRUS, SECRETARY
}

\section{GEOLOGICAL SURVEY}

H. William Menard, Director

For additional information write to:

U. S. Geological Survey

1815 University Avenue

Madison, Wisconsin 53706 


\section{CONTENTS}

$\underline{\text { Page }}$

Factors for converting inch-pound units to International System of Units (SI) -

Abstract---- -

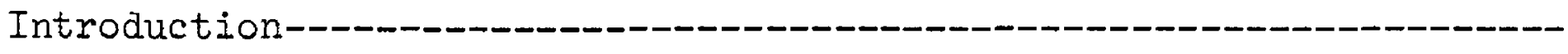

Purpose and scope--- - - - - - - - - - - - - - - - - - - - - - - - - - -

Location and physical description of study area-----------

Acknowledgments------

Hydrogeology of the area--

Source of water----

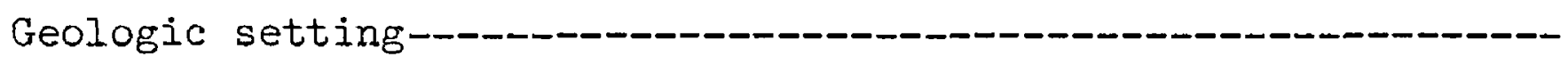

Ground-water occurrence and movement-_-

Water quality----

Ground water--

Lake water-------

Hydrology of Cedar Lake--

Lake-level fluctuations--

Relationship of lake levels to ground-water levels and

precipitation----

Water budget--

Budget equations----

Parameter determination--

Analysis of residual term-

Other observations---1--

Response to hydrologic system to pumping ground water into

Cedar Lake--

Background-_-_-_-_-_- 24

Ground-water-level changes near Cedar Iake----_---_-_--------- 24

Water-level changes in Cedar Lake---------- 25

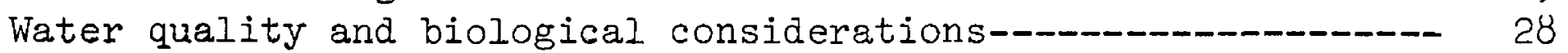

Summary and conclusions-

References cited-_- 34

\section{ILLUSTRATIONS}

Figure 1. Map showing location of study area in Wisconsin-------- 4

2. Map showing bedrock topography-_._- 7

3. Hydrogeologic section-..- 8

4. Map showing water table and direction of ground-water movement_-_-_-_- 9

5-10. Graphs showing:

5. Variation in lake stages, 1946-76 (annual maximum and minimum monthly mean stage and

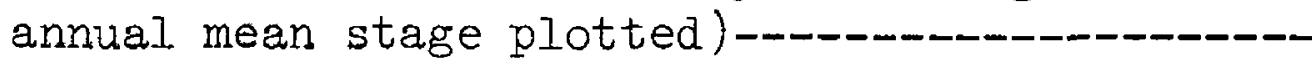

6. Frequency curve of annual maximum monthly mean

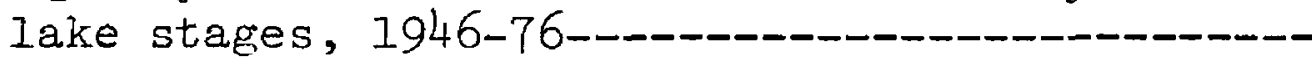


7. Frequency curve of annual minimum monthly mean lake stages, 1946-76__._. 15

8. Seasonal variation in mean monthly lake stage---- 15

9. Comparison between lake levels and ground-water levels-_-_- 16

10. Comparison between lake levels and precipitation- 17

11. Map showing depth of water in Cedar Lake and location

of monitoring sites-_-_-_-_-_- 18

12. Map showing water table and ground-water flow near

Cedar Lake, October 28, 1975-_-_._-_-_-_-_-_-_ 23

13. Map showing water table and ground-water flow near

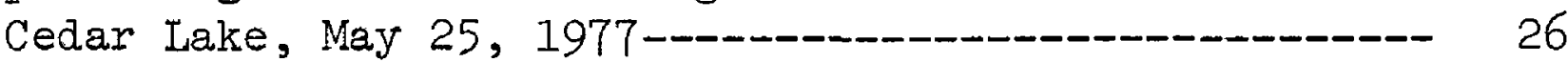

14-17. Graphs showing:

14. Relation between precipitation, pumping, and lake stage, water year 1977-_-_-_-_-_-_-_-_-_ 27

15. Observed temperature distribution in Cedar Lake,

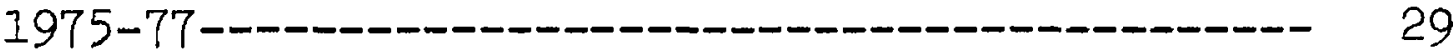

16. Observed dissolved-oxygen distribution in Cedar Lake, 1975-77-_-_- 30

17. Observed total nitrogen and total phosphorus concentrations of water in Cedar Lake at site A 31

\section{TABLES}

lable 1. Generalized stratigraphy and aquifer characteristics--.-- 5

2. Summary of chemical analyses of rainfall, lake water, and ground water-_-_-_-_-_ 11

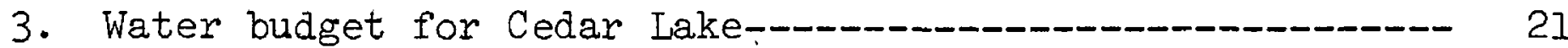

4. Measured phytoplankton population at site A, 1974-77--.-- 33

\section{CONVERSION FACTORS}

The following factors may be used to convert the inch-pound units to the International System of units (SI).

\section{Multiply}

acre

foot ( $f t$ )

square mile $\left(\mathrm{mi}^{2}\right)$

mile $(\mathrm{mi})$

inch (in.)

gallon per minute (gal/min)
By

0.004047

0.3048

2.590

1.609

2.540

0.06309
To obtain

square kilometer $\left(\mathrm{km}^{2}\right)$ meter $(\mathrm{m})$ square kilometer $\left(\mathrm{km}^{2}\right)$ kilometer $(\mathrm{km})$ centimeter $(\mathrm{cm})$ liter per second ( $\mathrm{L} / \mathrm{s})$ 


\title{
The Effects of Using Ground Water to Maintain Water Levels of Cedar Lake, Wisconsin
}

\author{
R. S. McLEOD
}

\begin{abstract}
Cedar Lake, a kettle lake with no surface inlet or outlet, was studied to evaluate the feasibility of maintaining water levels of lakes in the glaciated kettle moraine area of eastern Wisconsin by pumping ground water into them. The general hydrogeology of the area around the lake was defined and the hydrology of the lake was studied in detail.

There are two aquifer systems in the Cedar Lake area, and in general, throughout eastern Wisconsin. The shallow aquifer system is composed of unconsolidated glacial drift of Quaternary age and consolidated bedrock of Silurian age. Cedar lake is located in a local recharge area within this system. The saturated thicknesses of the glacial drift and Silurian dolomite beneath the lake are approximately 100 feet and 500 feet, respectively. This aquifer system is separated from an underlying aquifer system by a layer of shale approximately 200 feet thick that forms an effective barrier to water movement. The deep aquifer system is composed of dolomites and sandstones of Ordovician and Cambrian age whose composite thickness is 600 to 650 feet.
\end{abstract}

A water budget was prepared to quantify the components of the hydrologic system of Cedar Lake. Inflow to the lake averaged approximately 45 inches per water year for the 2-year period October 1974 through September 1976. Inflow consisted of precipitation on the lake surface (28 inches), groundwater seepage to the lake ( 2 inches), and overland flow ( 15 inches) to the lake. Outflow averaged approximately 49 inches per year for the same 2year period. Outflow consisted of evaporation (31 inches) from the lake surface and ground-water seepage from the lake (18 inches).

A volume of water equivalent to that needed to raise the lake level 47 inches was pumped from the shallow aquifer system into Cedar Lake between February 1 and September 30, 1977. The water budget for the lake 
during this period indicated that approximately 90 percent of pumped water was either recycled from the lake to the well or otherwise lost as seepage from the lake.

Selected physical and chemical characteristics of the lake water were measured periodically between October 1974 and September 1977. The water temperature ranged between $26^{\circ} \mathrm{C}$ in August to approximately $2^{\circ} \mathrm{C}$ in December during each year of the study. The dissolved-oxygen concentration of the water ranged from 13 milligrams per liter at the time ice cover first developed in December to 4 milligrams per liter at the time ice cover broke up the following April. The total nitrogen concentration of the water varied from 1.0 milligrams per liter during winter to 0.5 milligrams per liter during summer. The total phosphorus concentration of the water was fairly uniform throughout the year, averaging 0.01 milligrams per liter.

The phytoplankton population was sampled periodically. The total phytoplankton count was small during winter, generally less than 250 cells per milliliter. These phytoplankton were composed of euglenoids, diatoms, green algae, and blue-green algae. The count increased to 50,000 to 100,000 cells per milliliter during summer. One or two species of blue-green algae dominated during these times.

There were no identifiable changes in measured physical and chemical characteristics of lake water during sustained pumping of ground water into the lake, nor were there identifiable changes in the number or makeup of the phytoplankton community. Differences in physical and chemical characteristics of lake water and ground water added to the lake probably were not great enough to cause changes within the lake.

\section{INTRODUCTION}

The Wisconsin Department of Natural Resources (DNR) has received numerous requests concerning the feasibility of maintaining water levels of lakes by pumping ground water into them. Although qualitative answers could be given to these requests, there have been little or no data collected on the hydrologic consequences of such an undertaking.

The DNR granted a well construction permit to Sanitary District No. I, Town of Schleswig, in 1971. The well was to be constructed near Cedar lake and used to pump ground water into the lake in an attempt to maintain the lake stage at or near its long-term average altitude of approximately $888.5 \mathrm{ft}$. The well was constructed in the winter of 1971-72.

Before granting this permit, the DNR advised the sanitary district that, because of hydrologic conditions in the area, the well might fail to be of value as an aid to controlling lake stages. In October 1973, the U.S. Geological Survey and the DNR entered into a cooperative agreement to study the hydrology of Cedar Lake and hydrologic changes that might result from pumping ground water into the lake. 
Field data were collected between February 1974 and September 1977. Data collected during water years 1975, 1976, and 1977 (October 1, 1974, through September 30, 1977) were sufficient to prepare a water budget defining components of inflow and outflow for Cedar lake both before and during pumping.

\section{PURPOSE AND SCOPE}

The purpose of this study was to evaluate the effects of using ground water to maintain the level of Cedar Lake. The report describes the relationship between various hydrologic factors and water-level fluctuations and the response of the hydrologic system to pumping ground water into the lake.

\section{LOCATION AND PHYSICAL DESCRIPTION OF STUDY AREA}

The study area includes Liberty, Eaton, Schleswig, and Meeme Townships, an area of $144 \mathrm{mi}^{2}$ in the southwest corner of Manitowoc County (fig. 1 ).

Cedar Lake is in Schleswig Township $5.1 \mathrm{mi}$ east of Kiel, Wis. The lake is a land-locked kettle lake with a surface area of 142 acres and maximum depth of $22 \mathrm{ft}$ at mean lake level. The lake drains an area of I. $33 \mathrm{mi}^{2}$.

\section{ACKNOWLEDGEMENTS}

The cooperation and helpfulness of residents within the study area is gratefully acknowledged. Many persons allowed access to their wells for water-level measurements and for collecting water samples for chemical analysis. Mr. Raymond R. Zywicki provided an easement for installation of the lake-stage recorder at Cedar Lake. Sanitary District No. 1, Town of Schleswig, Manitowoc County, provided the use of their facilities for the long-term pumping test described in this report.

\section{HYDROGEOLOGY OF THE AREA}

\section{SOURCE OF WATER}

The source of all water in the study area is precipitation. Much of the precipitation on the land surface is returned to the atmosphere by evaporation or transpiration. The remainder flows overland to streams or lakes, replenishes soil moisture, or percolates downward to the water table.

\section{GEOLOGIC SETTING}

The area is underlain by rocks of Precambrian, Cambrian, Ordovician, Silurian, and Quaternary age. A stratigraphic column representing the sequence of rocks is given in table 1 . 


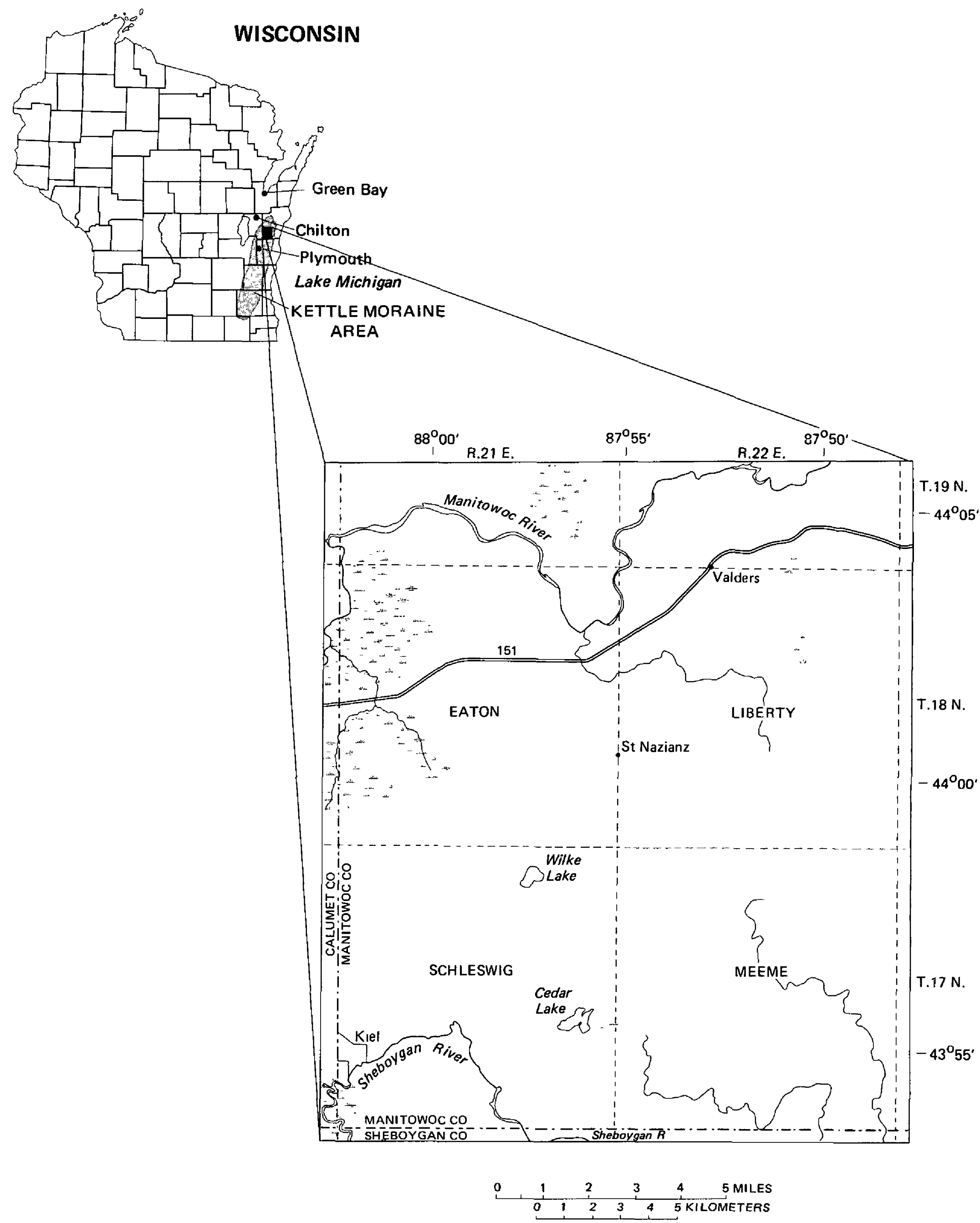

Figure 1. Location of study area in Wisconsin. 


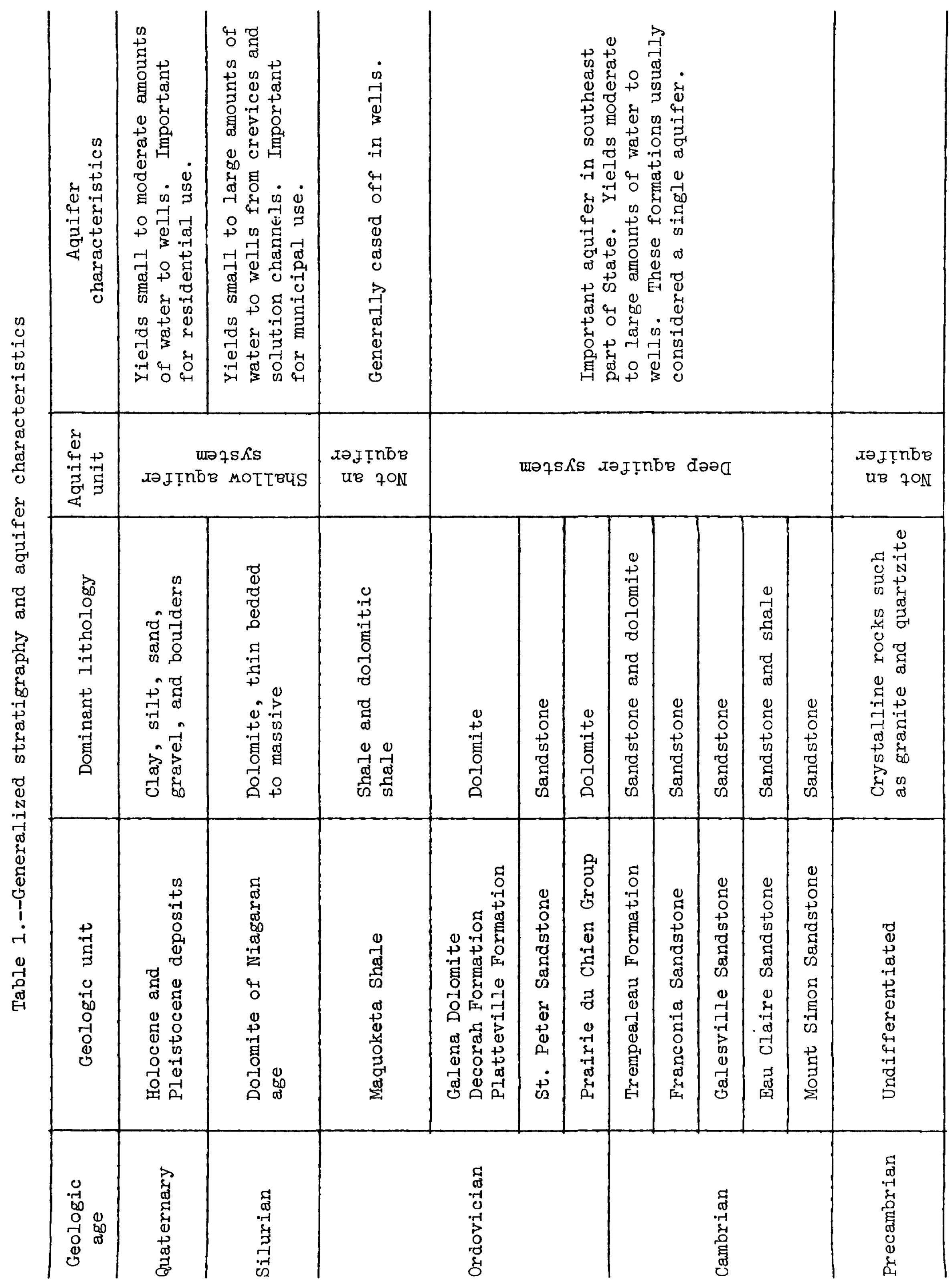


Dense crystalline rock of Precambrian age forms the basement upon which sediments were deposited. The depth below land surface to the Precambrian rocks is about 1,400 ft (Weidman and Schultz, 1915, p. 263). These rocks are relatively impermeable and are assumed to form the base of the aquifer system.

A layered sequence of gently eastward dipping sedimentary rocks of Cambrian and Ordovician age overlie the Precambrian rocks. These rocks are mainly sandstone and dolomite with a composite thickness of 600 to $650 \mathrm{ft}$. They are saturated throughout their thickness and are a potential source of water supply.

Silurian dolomite of Niagaran age overlies the Ordovician rocks and is the upper bedrock unit. This unit is mostly dense dolomite with many joints and solution channels. Its thickness ranges between 400 and $600 \mathrm{ft}$. It is saturated in most of the study area and is a principal source of water for municipal wells and for many privately owned wells.

The bedrock topography map (fig. 2) shows the shape of the bedrock surface. This surface was shaped mainly by preglacial and glacial erosion. Its dominant feature is a valley that extends across the study area and deepens to the southeast.

Unconsolidated glacial deposits of Quaternary age overlie the bedrock to thicknesses between 20 and $100 \mathrm{ft}$. The thickness beneath Cedar Lake is approximately $100 \mathrm{ft}$. These deposits consist of stratified clay, sand and gravel, and unstratified till. They are saturated throughout their thickness directly under lakes and streams that are in hydraulic contact with the water table. These deposits are a major source of water for privately owned wells.

\section{GROUND-WATER OCCURRENCE AND MOVEMENT}

Water is present in glacial deposits and in the underlying bedrock. In glacial deposits, water occurs in intergranular pore spaces. In bedrock units, water occurs in fractures, joints, and solution openings as well as in intergranular pore spaces. Precambrian crystalline bedrock is assumed to be the lower limit of the ground-water reservoir because it is relatively impermeable. The water table in the Quaternary age glacial deposits is the upper limit of this reservoir.

The ground-water reservoir consists of two aquifer systems ( $f i g .3$ ). The shallow aquifer system is composed of the unconsolidated glacial deposits and consolidated dolomite bedrock of Niagaran age. This aquifer system is separated from an underlying sandstone aquifer system by the Maquoketa Shale which does not transmit water readily. The sandstone aquifer is composed of dolomites and sandstones of Ordovician and Cambrian age.

Water movement in the sandstone aquifer is generally from west to east (Skinner and Borman, 1973, pl. 2). These units receive most of their water $30 \mathrm{mi}$ or more to the west, where they are upper bedrock units and are easily recharged. They discharge their water into Lake Michigan approximately $10 \mathrm{mi}$ to the east. 


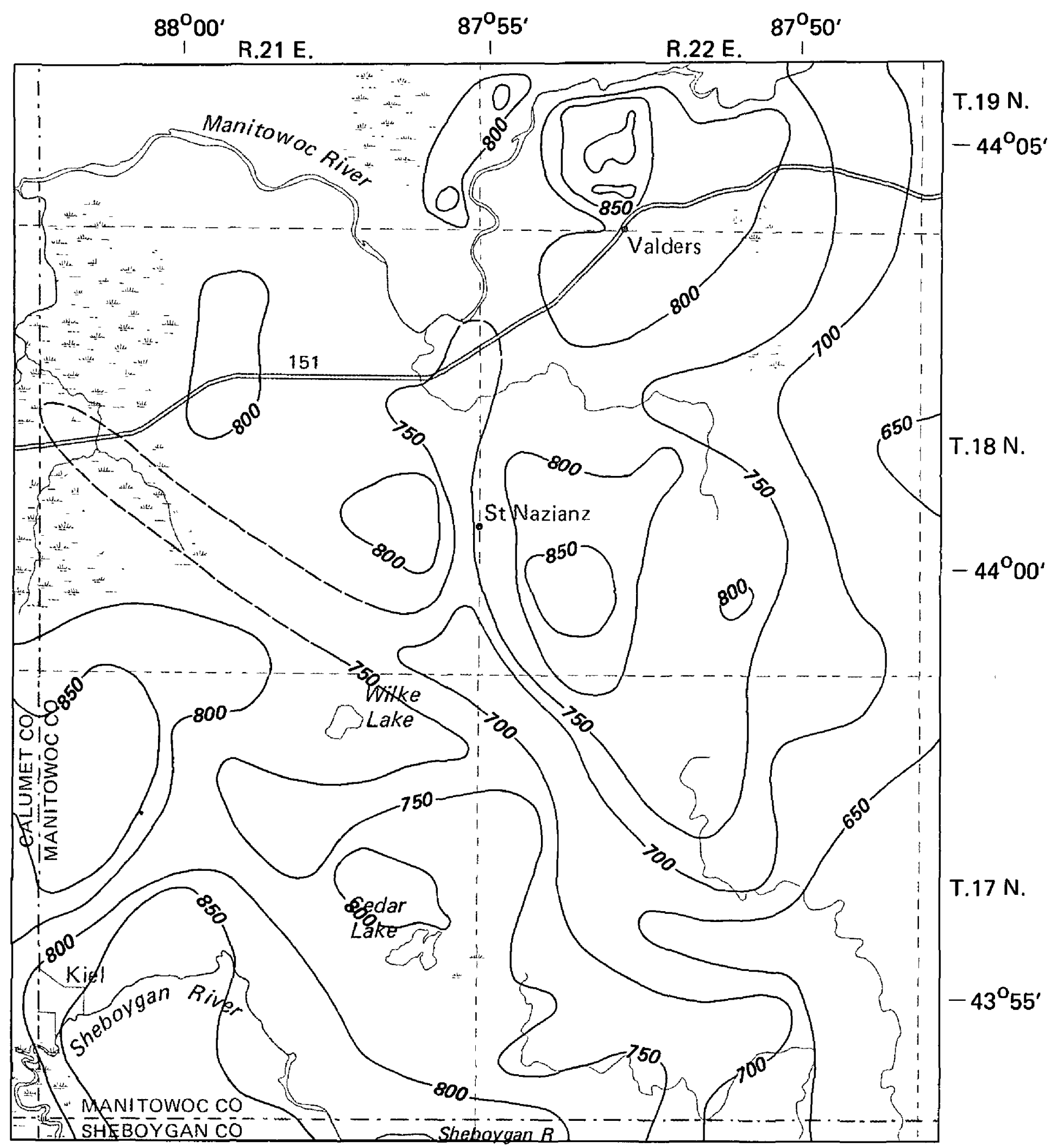

Base from U. S. Geological Survey

$1: 62,500$ quadrangles

\begin{tabular}{rrrrrrr}
0 & 1 & 2 & 3 & 4 & 5 MILES \\
\hline 0 & 1 & 2 & 3 & 4 & 5 KILOMETERS
\end{tabular}

EXPLANATION

Bedrock contour

Shows altitude of bedrock surface.

Dashed where approximate.

Contour interval 50 feet. Datum

is mean sea level

Figure 2. Bedrock topography. 
Flow directions in the shallow aquifer system were determined from the shape of the water table (fig. 4). Water-table contours were drawn using altitudes of streams, lakes, and water levels in wells. Ground water flows at approximately right angles to these contours from areas of higher head to areas of lower head.

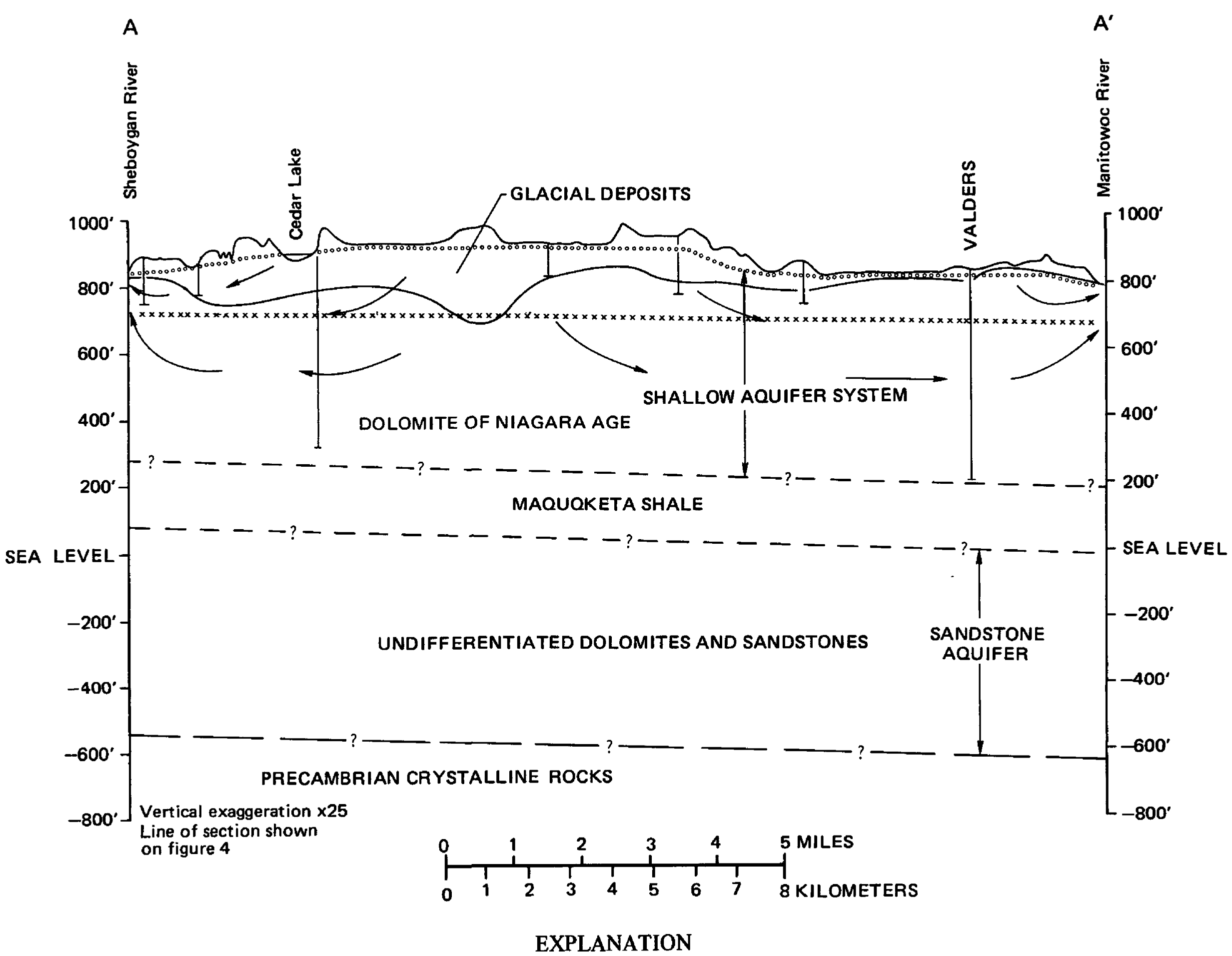

Water table

Generalized direction of groundwater movement.
Estimated potentiometric surface of deep aquifer

Figure 3. Hydrogeologic section. 


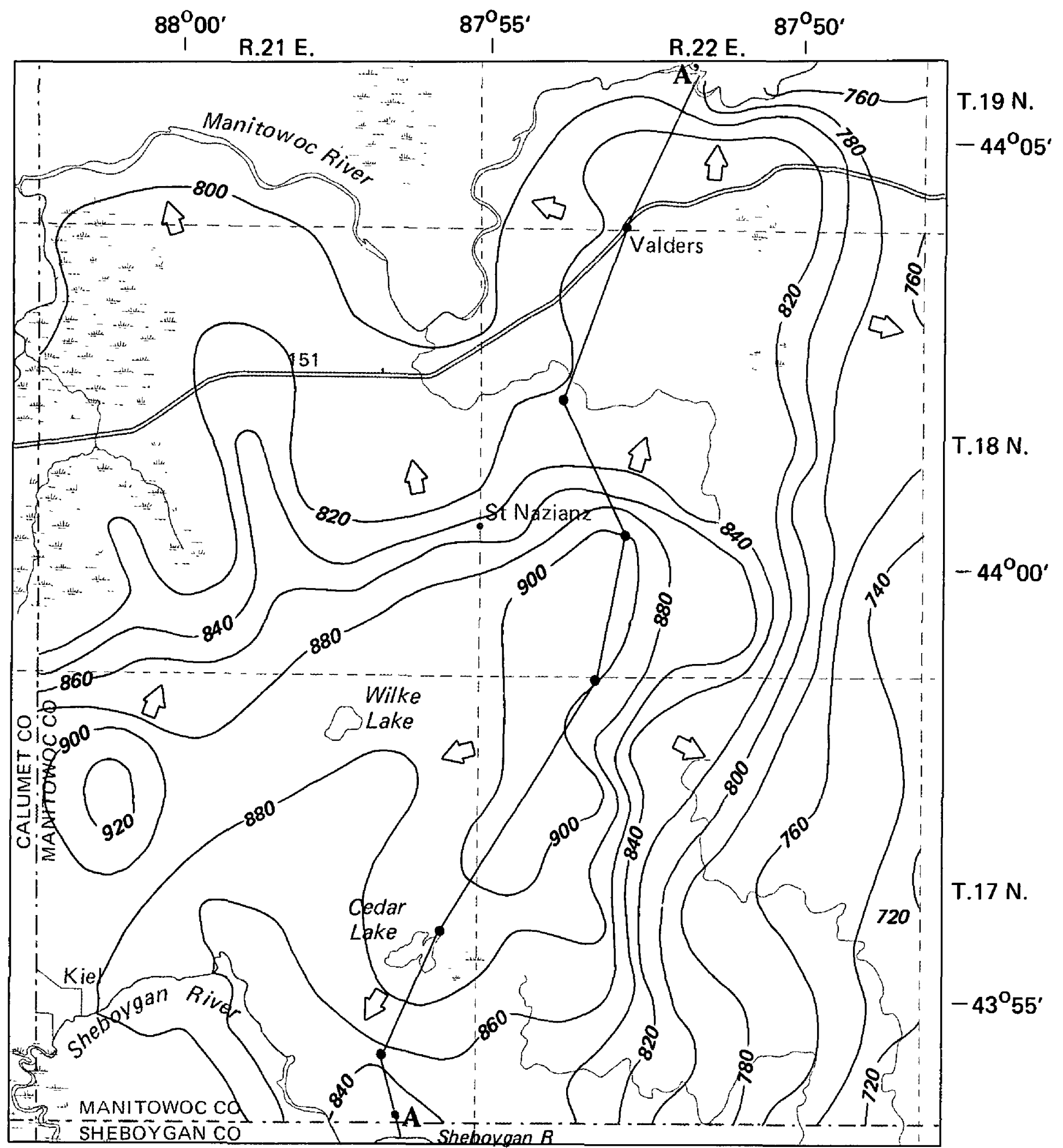

Base from U. S. Geological Survey

1:62,500 quadrangles

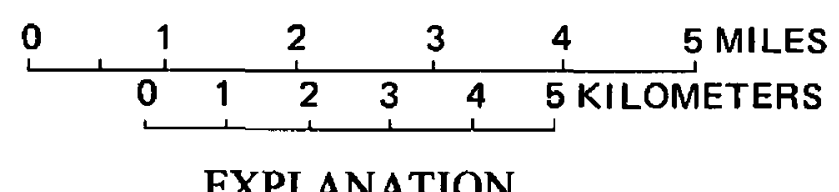

\section{EXPLANATION}

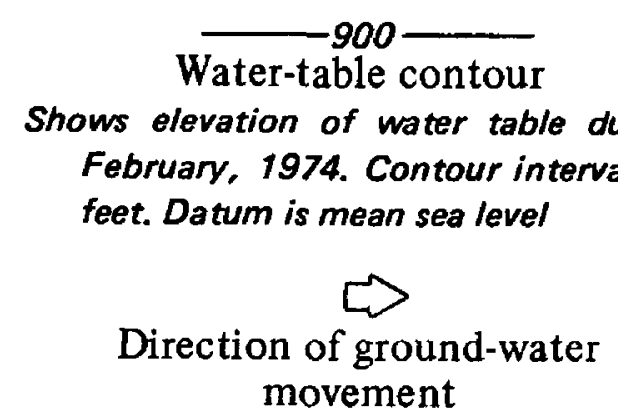

$$
\begin{gathered}
\mathbf{A}-\mathbf{A}^{\prime} \\
\text { Line of hydrogeologic section } \\
\text { shown in Figure } 3
\end{gathered}
$$

Figure 4. Water table and direction of ground-water movement. 
The water table is a subdued replica of the topography. In general, the local topographic high areas are a regional ground-water recharge area for the shallow aquifer system, a recharge area being defined as an area where the vertical component of ground-water flow is downward. The Manitowoc and Sheboygan River valleys are topographic low areas. These valleys are regional ground-water discharge areas or areas where the vertical component of ground-water flow is upward. Lake Michigan, approximately $10 \mathrm{mi}$ east of Cedar Lake, is also a topographic low area and an area of regional groundwater discharge. Ground water that flows north from the regional recharge area discharges into the Manitowoc River. Ground water that flows south from this recharge area discharges into the Sheboygan River. Ground water that flows east from this recharge area discharges into Lake Michigan or small streams tributary to Lake Michigan.

\section{WATER QUALITY}

The chemical characteristics of ground water in the area depends upon the chemical characteristics of the soil and rock materials. Precipitation, the source of water, has few minerals in solution before it reaches the ground (table 2). However, as it percolates through the ground or runs off over the land surface, it dissolves minerals.

Water samples were taken from 5 lakes and 37 wells to identify the chemical characteristics of lake water and ground water. Eight samples were from wells that withdraw their water from the glacial drift. The remaining 29 well samples were from wells that withdraw their water from the Niagaran dolomite. Twenty-two wells in the Niagaran dolomite penetrate less than $105 \mathrm{ft}$ of bedrock. The remaining seven wells penetrate $290 \mathrm{ft}$ or more of bedrock. The results of these analyses are presented in table 2 .

\section{Ground water}

Calcium, magnesium, and bicarbonate are the predominate cations and anions in solution in water from both the glacial deposits and Niagaran dolomite. This is typical of many ground waters in the state that are in contact with dolomitic rocks.

There is no significant difference in mineral concentration between water withdrawn from glacial deposits and water withdrawn from the upper $105 \mathrm{ft}$ of Niagaran dolomite. This conclusion is based on a statistical comparison of dissolved-solids concentration data. This analysis suggested that differences experienced here are probably due to chance variation.

Also, the dissolved mineral concentration of water from wells in bedrock does not differ significantly with the depth of the well. Dissolvedsolids concentrations were compared for water samples from wells that penetrate less than $105 \mathrm{ft}$ of bedrock with those that penetrate more than $290 \mathrm{ft}$. The differences experienced here were probably due to chance variation. 


\begin{tabular}{|c|c|c|c|c|c|c|}
\hline & 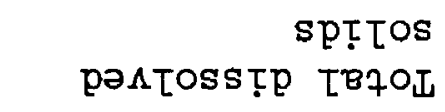 & J & 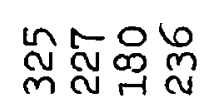 & 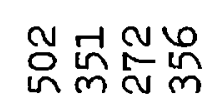 & 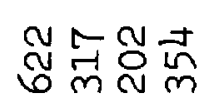 & $\begin{array}{l}\mathbb{N} \\
\mathbb{N} \\
\end{array}$ \\
\hline & $\left({ }^{2} 0 ! S\right)$ BotT!S & $\dot{-1}$ & 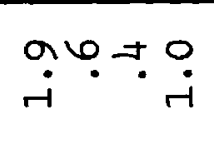 & 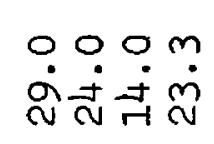 & 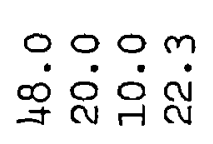 & 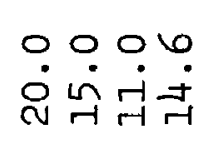 \\
\hline & 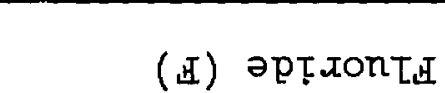 & $\ddot{0}$ & 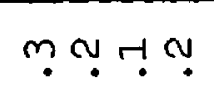 & ナ. & ᄂ & 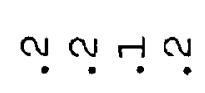 \\
\hline$\underset{+}{+}$ & (पW) әsəuвgurW & 0 & t5유 & ผ ㅇํำ & 덛교 & in 000 年 \\
\hline 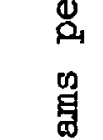 & 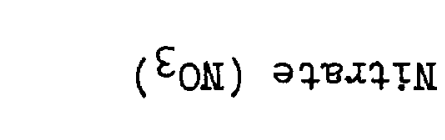 & $\dddot{\Upsilon}$ & 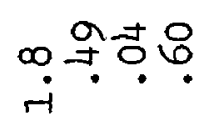 & $\underset{r}{\infty} \stackrel{m}{r} \stackrel{m}{\sim}$ & $\mathrm{m}^{\circ}$ & $\approx \dot{\sim} \dot{0} \cdot \vec{\theta}$ \\
\hline 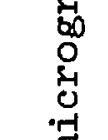 & 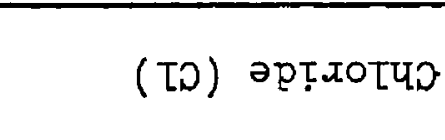 & $\dot{0}$ & : & $\begin{array}{l}\mathscr{0} 0 \dot{m} \\
\dot{\sim} \dot{m} \dot{m}\end{array}$ & 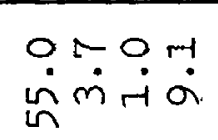 & $\begin{array}{l}0 \\
\dot{m} \\
\dot{m}\end{array} \dot{m} \dot{m}$ \\
\hline 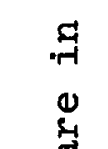 & ( TOS) ә78ITnS & $\stackrel{\infty}{\dot{\sim}}$ & 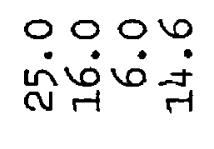 & o̊ & 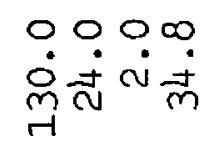 & 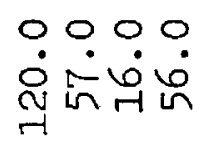 \\
\hline ef & 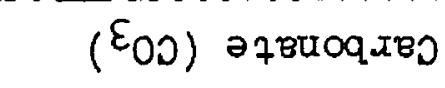 & 0 & $\underset{\text { N }}{\mathrm{N}}$ OON & 0000 & 0000 & 00 \\
\hline $\begin{array}{l}\text { 秀 } \\
0\end{array}$ & 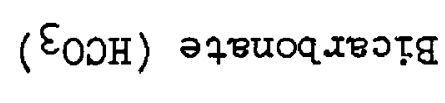 & $m$ & 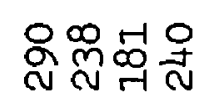 & 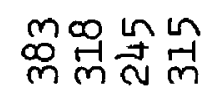 & 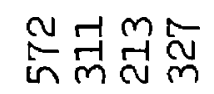 & 尔 mân \\
\hline 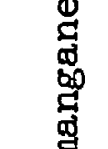 & $\left(\partial_{1}\right.$ I $)$ uoxI & i & 잉웅 & 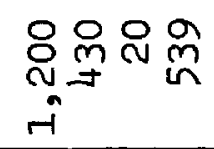 & 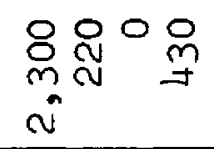 & 8 잉유 \\
\hline 'ृ్ష & (Y) unțssBzod & $\stackrel{\circ}{\circ}$ & 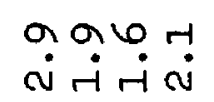 & i & ن & 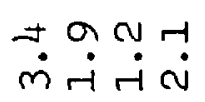 \\
\hline 袁 & (BN) umfpos & $\stackrel{\circ}{\circ}$ & $\begin{array}{l}\dot{q} \overrightarrow{+} \dot{m} \\
\dot{\tau} \dot{m} \dot{r} \dot{m}\end{array}$ & 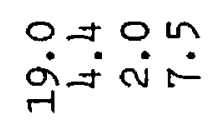 & $\dot{\sim} \vec{\sim} \dot{\sim} \dot{0}$ & 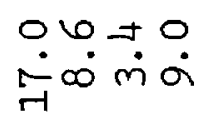 \\
\hline 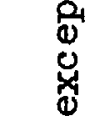 & 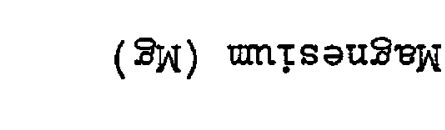 & $\dot{0}$ & 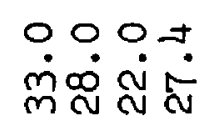 & 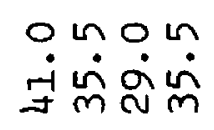 & 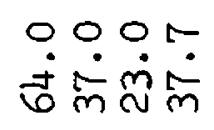 & 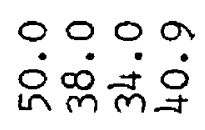 \\
\hline 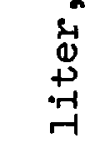 & (8D) unț०โBD & $\stackrel{\circ}{\circ}$ & $\begin{array}{l}00 \\
\dot{\theta} \dot{m} \\
\dot{y}\end{array}$ & 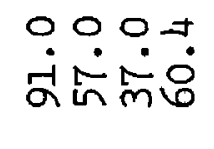 & $\begin{array}{l}00 \infty \\
\dot{\gamma} \\
\dot{\gamma}\end{array}$ & 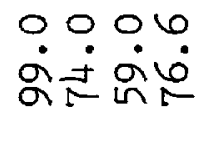 \\
\hline 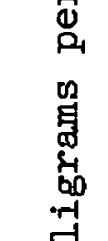 & 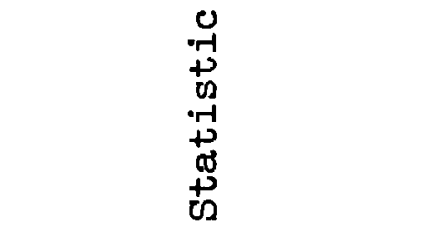 & & 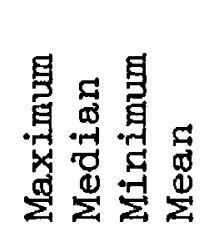 & 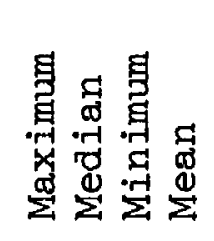 & 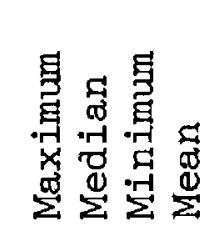 & 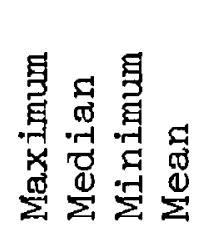 \\
\hline 尚 & 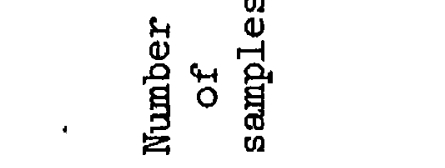 & $r$ & in & $\infty$ & N & 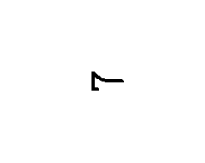 \\
\hline 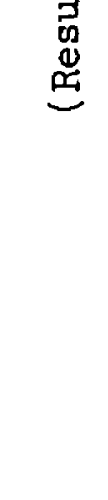 & 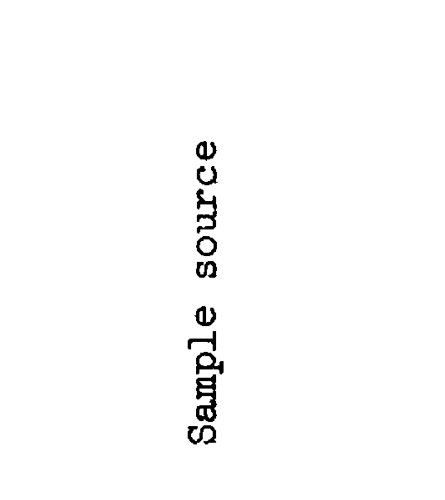 & 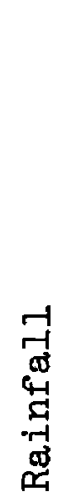 & 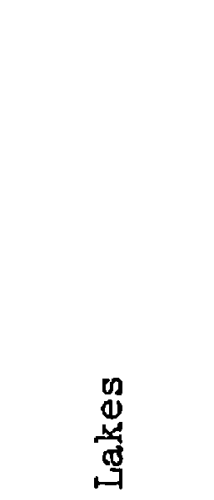 & 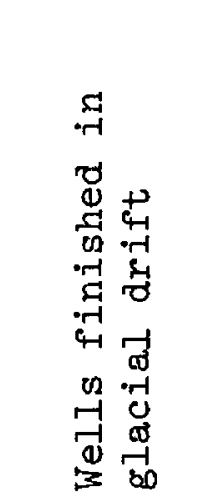 & 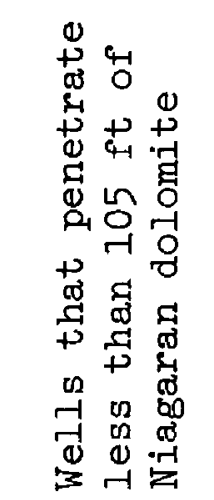 & 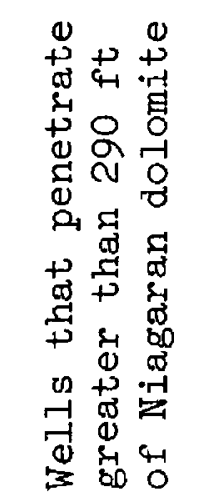 \\
\hline
\end{tabular}


Water in the sandstone aquifer underlying the Maquoketa Shale may be more highly mineralized than water in the overlying glacial drift and Niagaran dolomite. Dissolved-solids coneentrations greater than $2,000 \mathrm{mg} / \mathrm{L}$ have been reported in water from wells that penetrate this aquifer (Ryling, 1961, p. 17). There were no wells available in the study area for sampling water from the sandstone aquifer.

\section{Lake water}

Lake water is less mineralized than ground water. A statistical analysis of dissolved-solids concentration data using small-sampling theory shows that differences in dissolved-solids concentrations of these two waters cannot be accounted for by chance variation. Precipitation on lakes and overland flow to lakes are responsible for the lower dissolvedmineral concentration of lake water.

\section{HYDROLOGY OF CEDAR LAKE}

\section{LAKE-LEVEL FLUCUATIONS}

Lake-stage measurements were made by the U.S. Geological Survey from August 1936 to September 1942 and from April 1945 to September 1977. Sufficient intermittent lake-stage measurements are available for the latter period to estimate monthly mean lake stages. Earlier data are too fragmentary to allow for reasonable estimates of monthly mean lake stages.

Lake stages varied considerably between 1946 and 1976. The minimum monthly mean stage during this period was $885.36 \mathrm{ft}$ above mean sea level in January 1959, and the maximum monthly mean stage was $891.17 \mathrm{ft}$ in May 1976. The maximum yearly fluctuation among monthly mean lake stages was $2.19 \mathrm{ft}$ in 1973, and the minimum yearly fluctuation was $0.40 \mathrm{ft}$ in 1962 . The average yearly fluctuation among monthly mean lake stages was $1.18 \mathrm{ft}$.

There was a tendency for lake stages to be related from one period of time to the next, in the sense that high values tended to follow low values.

This dependency decreases with increased time periods. The dependency between daily lake stages was very evident. Daily lake stages did not change appreciably from one day to the next. However, the dependency between monthly mean lake stages was less than between daily lake stages, and the dependency between yearly mean lake stages was even less than that between monthly mean stages.

The tendency for lake stages to cluster can be illustrated from a plot of yearly lake stage data for the period 1946-76 (fig. 5). Recent lake stages provide good examples. Low lake stages in 1968 were followed by low stages in 1969, 1970, 1971, and 1972. Similarly, high lake stages in 1974 were followed by high stages in 1975 and 1976. 


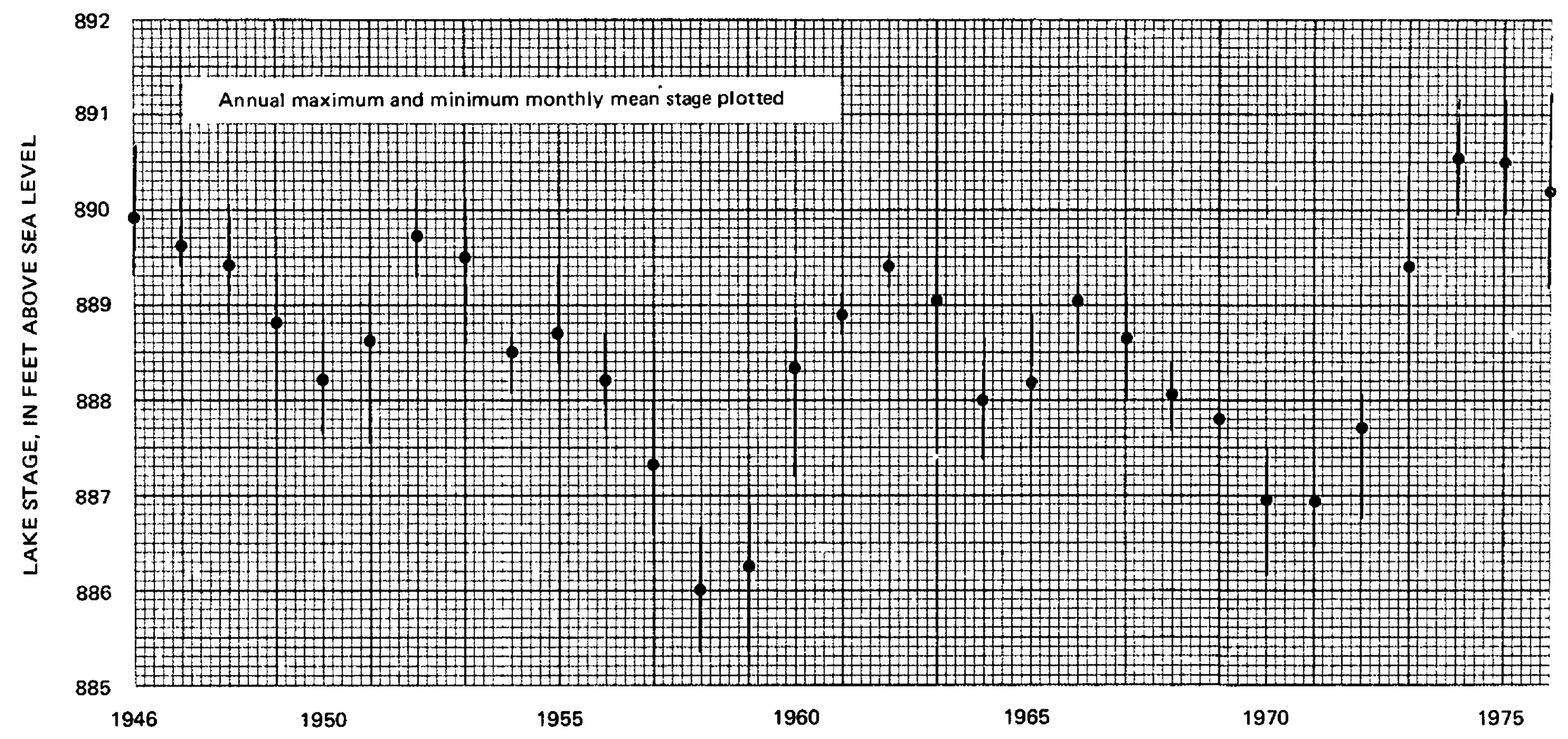

Figure 5. Variation in lake stages, 1946-76.

Frequency curves were used to relate annual maximum and minimum monthly mean lake stages to the frequency of their occurrence (figs. 6 and 7). These curves show the cumulative distribution of lake stages and were prepared using lake-stage data shown in figure 5.

Lake stages during the study were extremely high. Figure 6 suggests that a year with a maximum monthly mean lake stage equal to or greater than 891.0 ft could be expected to occur only about once every 15 to 20 years. The maximum monthly mean lake stages for 1974, 1975, and 1976 were each greater than $891.0 \mathrm{ft}$.

The reliability of the frequency curves must be qualified as being approximate representations of the true lake-stage frequency relationships. The frequency curves were constructed by disregarding the sequence of occurrence of individual stage measurements and assuming that each measurement was independent of all previous measurements. However, as noted above, a correlation does exist between individual values from one year to the next. The long period of record available for constructing the curves, however, partly offsets these effects and justifies the use of the curves. 
There has been a well-defined seasonal variation in lake stage during the period it has been measured. The ratio of mean lake stage for each month of the year to mean lake stage, using data for the period 1946-76, is plotted in figure 8 . Lake stages generally were at their highest levels between April and July and at their lowest levels between september and January. Rises in lake stages generally occurred between November and May and declines generally between May and November.

\section{RELATIONSHIP OF LAKE LEVELS TO GROUND-WATER LEVELS AND PRECIPITATION}

Lakes in the study area occur wherever the water table intersects the land surface. Thus, lake surfaces are simply visible parts of the water table.

Because lakes are part of the water table, lake levels and groundwater levels rise and fall in similar trends. In figure 9, fluctuations in ground-water levels in two observation wells located approximately $1 \mathrm{mi}$ north of Cedar Lake are compared with fluctuations in the level of the lake. Well $\mathrm{Mn}-2 \mathrm{ll}$ is open to the water table in the glacial drift approximately $50 \mathrm{ft}$ below land surface. Well $\mathrm{Mn}-210$ is open to the water table at the approximate contact surface between the glacial drift and Niagaran dolomite, $115 \mathrm{ft}$ below land surface. Water levels in these wells fluctuated in harmony with the lake level.

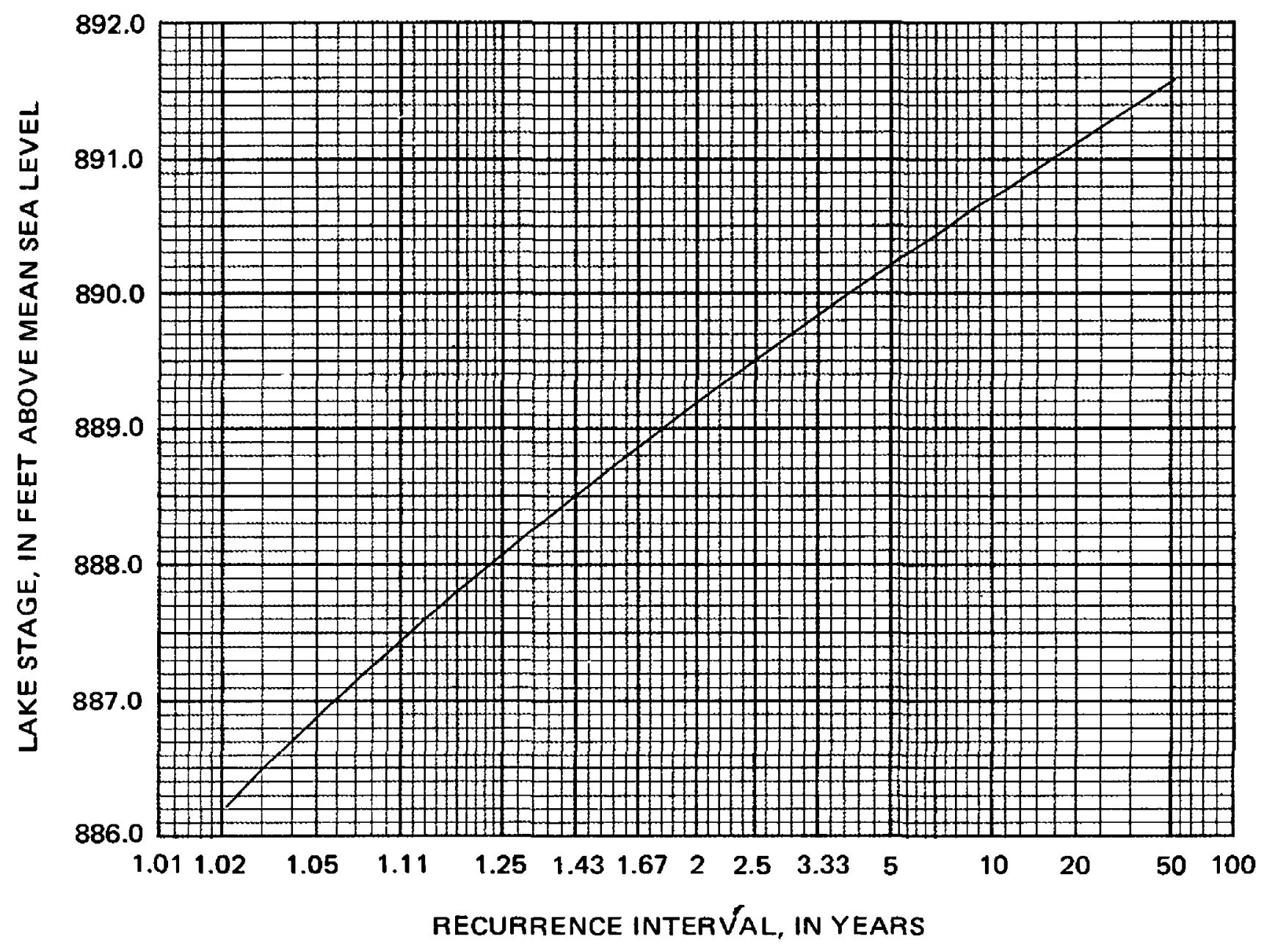

Figure 6. Frequency curve of annual maximum monthly mean lake stages, 1946-76. 


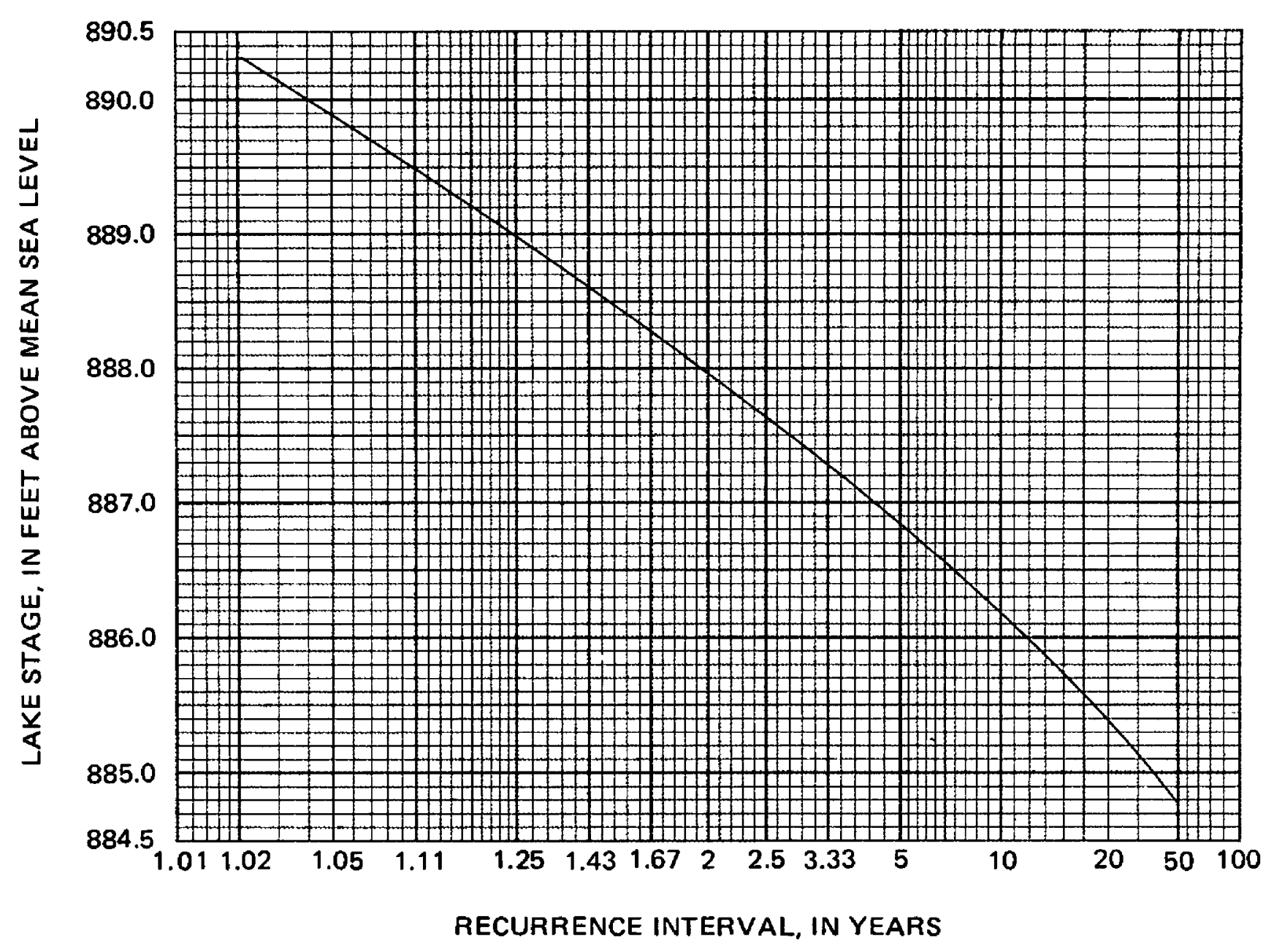

Figure 7. Frequency curve of annual minimum monthly mean lake stages, 1946-76.

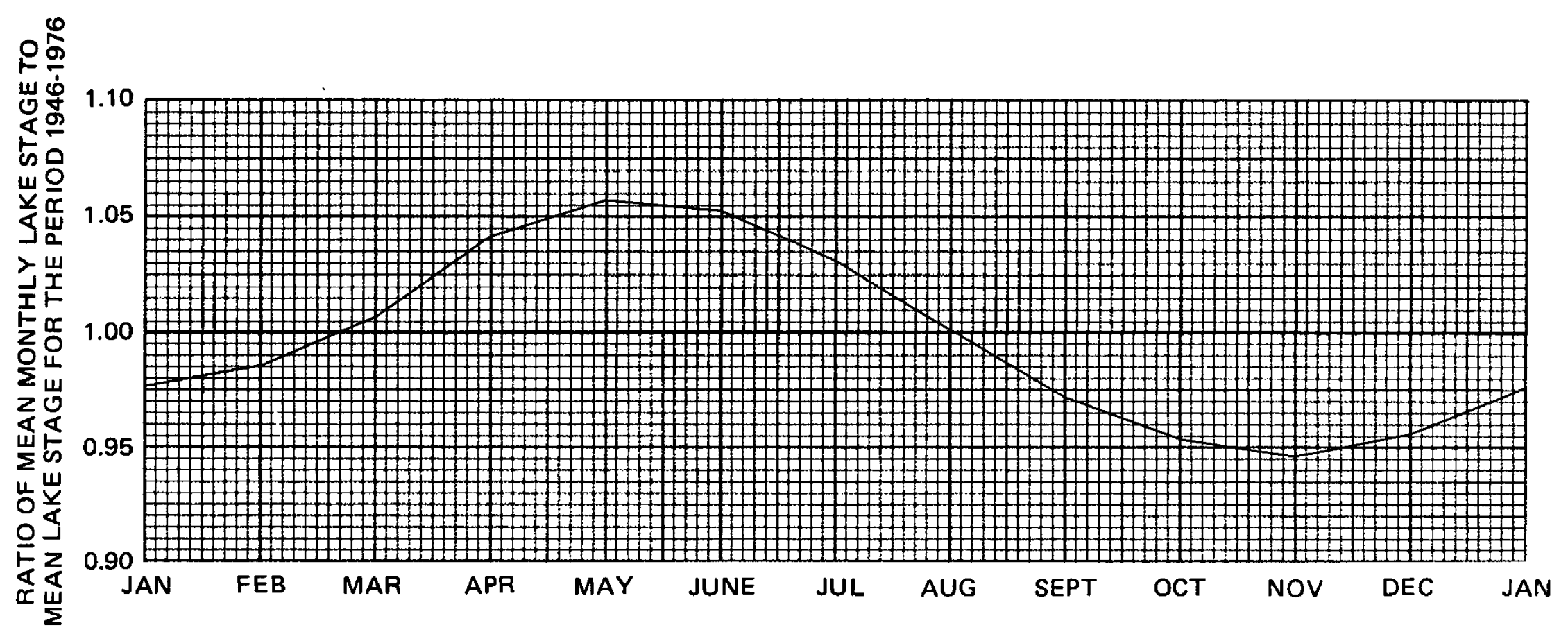

Figure 8. Seasonal variation in mean monthly lake stage. 

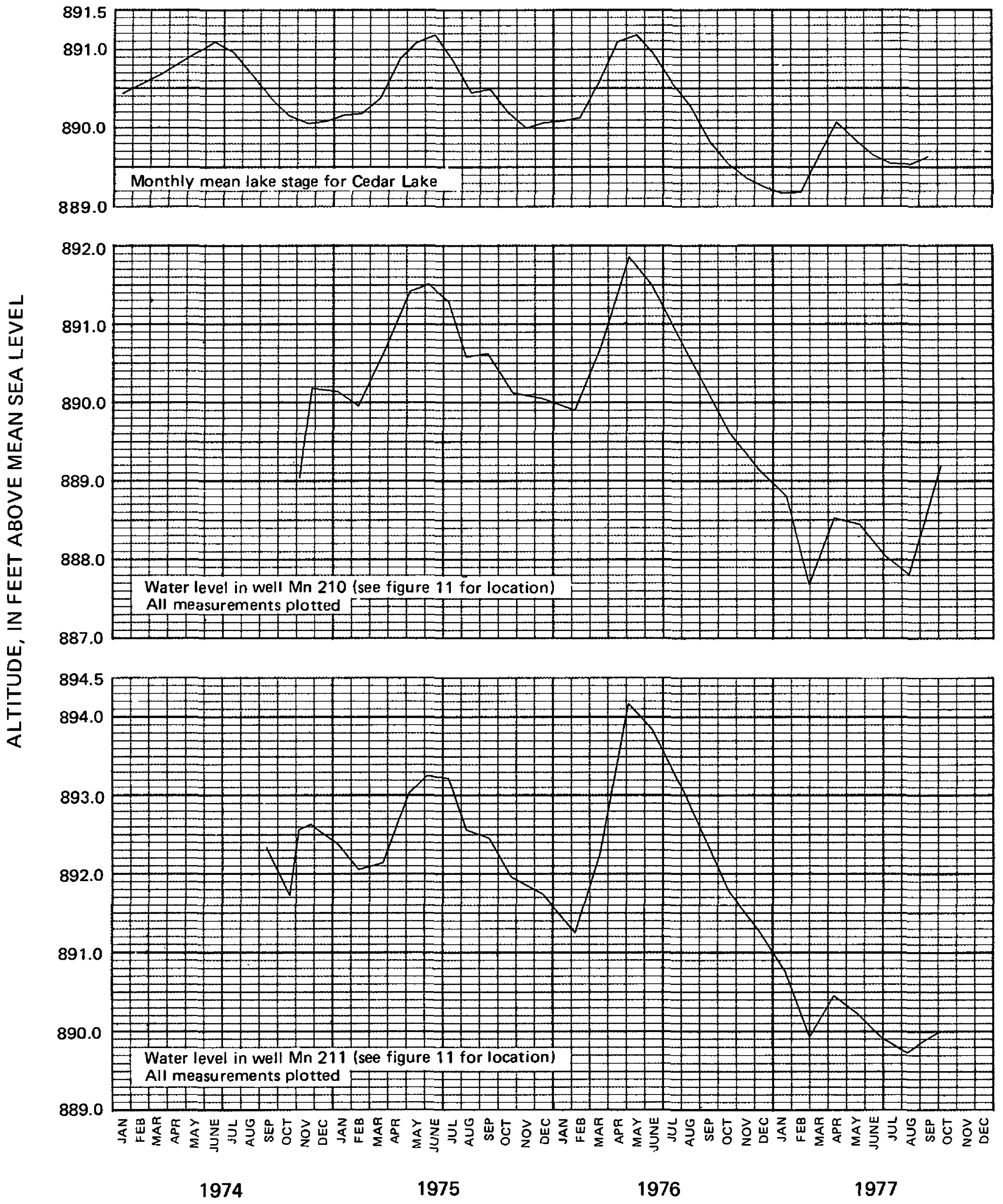

Figure 9. Comparison between lake levels and ground-water levels. 


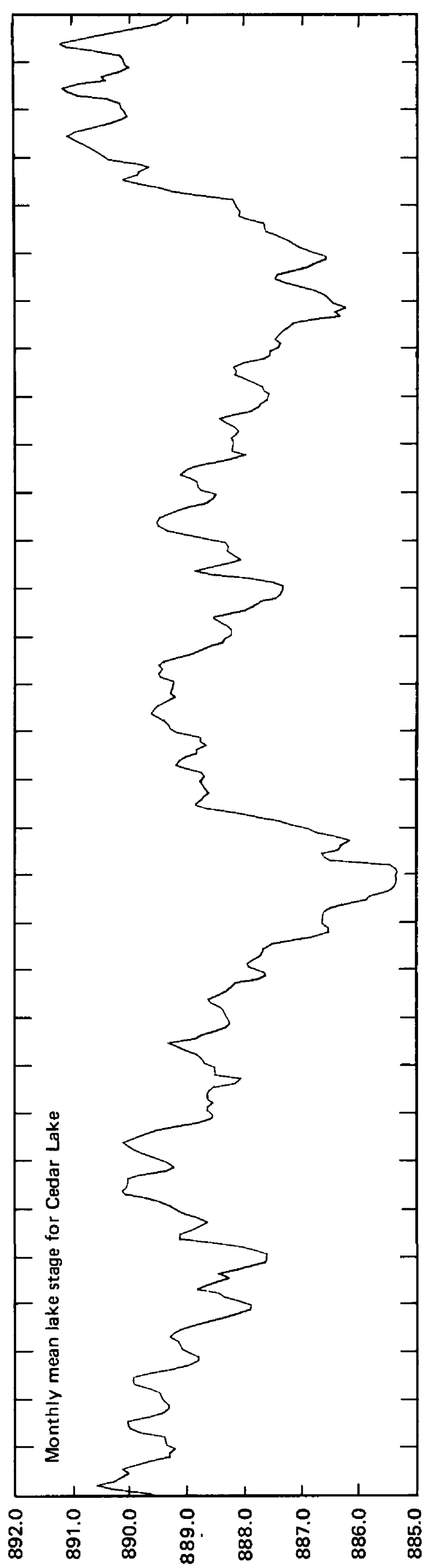

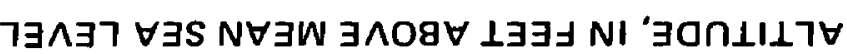

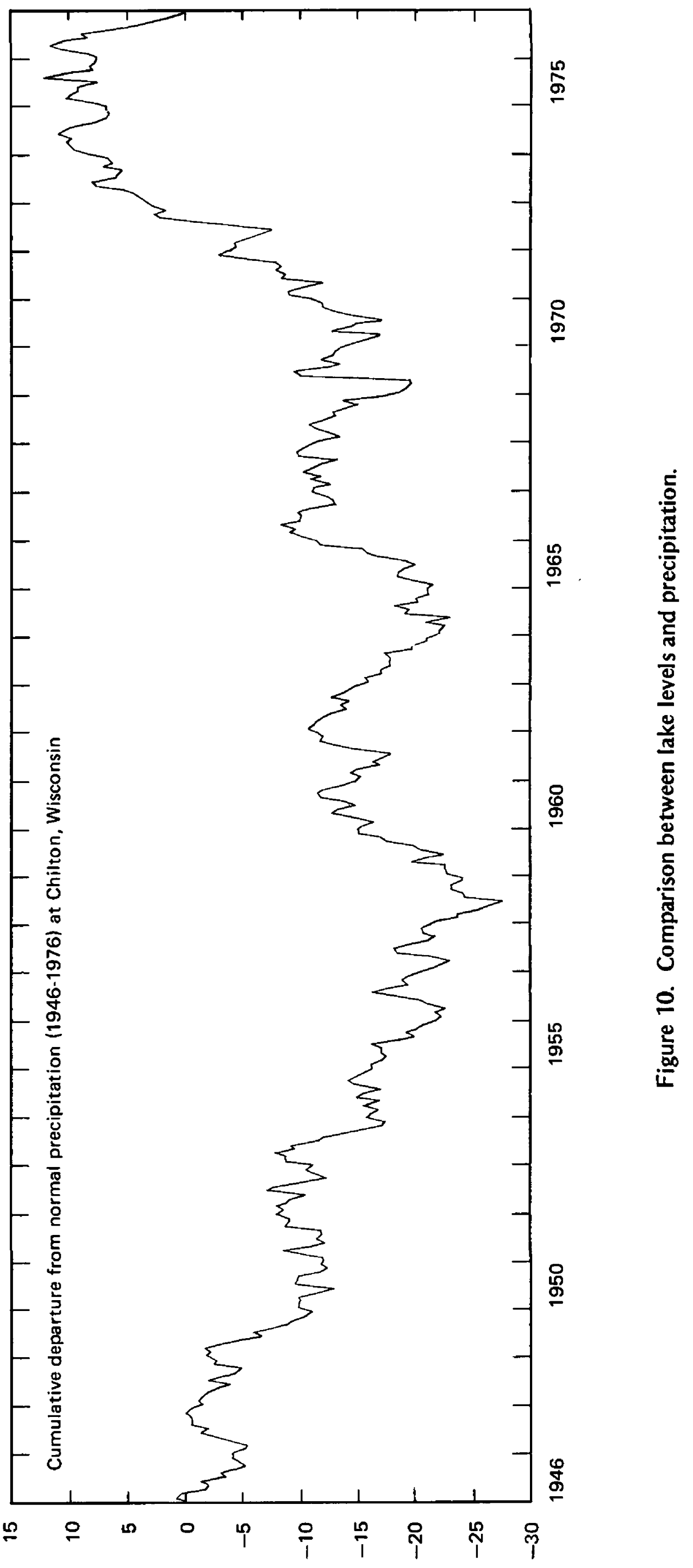

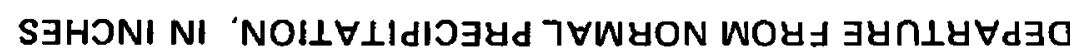


Seasonal trends in lake levels and ground-water levels reflected seasonal variations in precipitation, evaporation, and transpiration. In general, lake levels and ground-water levels in the area rose in early spring (fig. 9) in response to recharge to the water table. By midsummer, transpiration by plants plus evaporation generally exceeded precipitation,

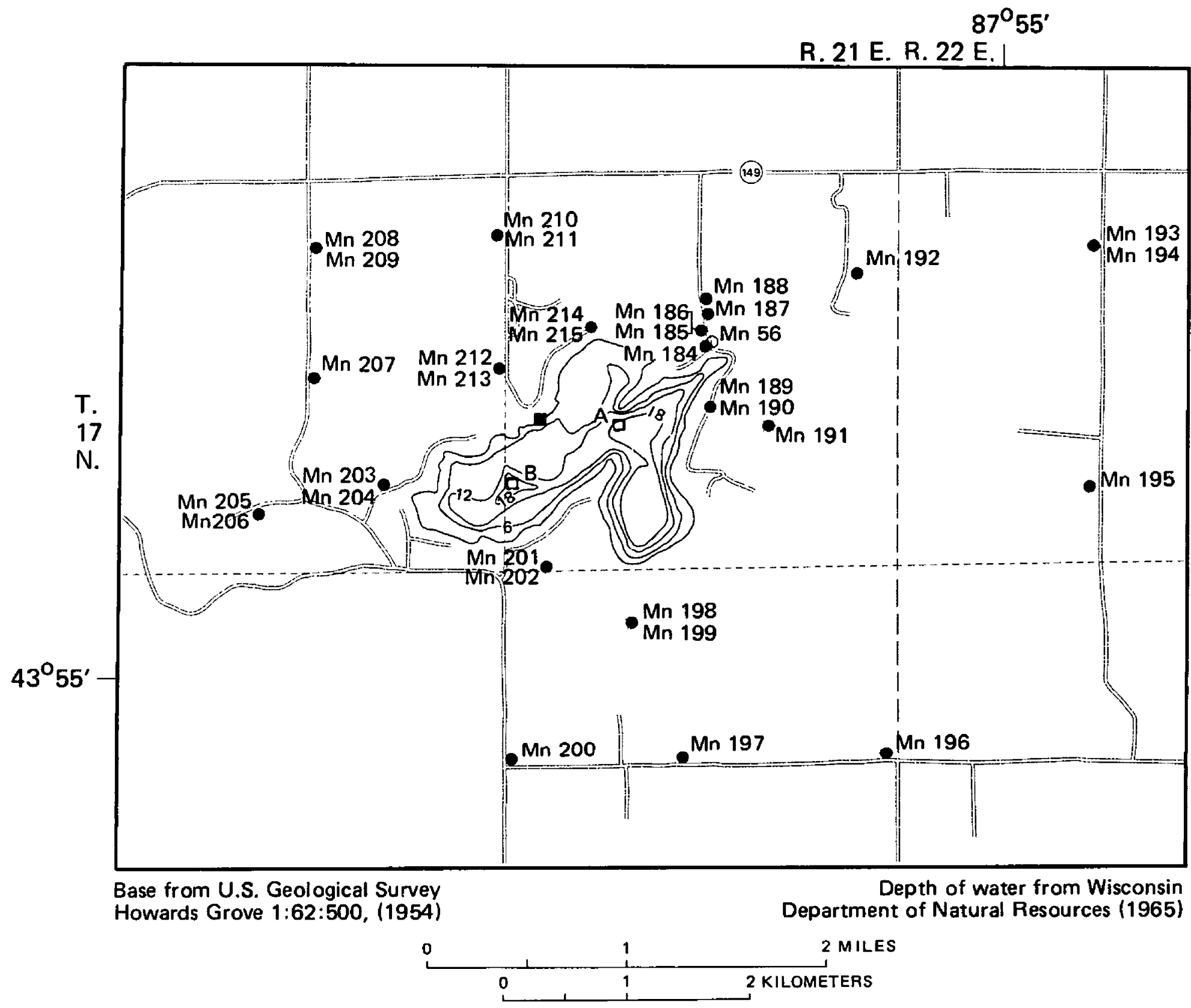

EXPLANATION

Mn 195 Well or piezometer and number

- Pumping well and recording precipitation gage

- Recording lake-stage gage
$\square^{A}$ Lake sampling site and site number

-12- Line of equal lake depth, in feet below mean lake level Interval 6 feet

Figure 11. Depth of water in Cedar Lake and location of monitoring sites. 
and water levels began receding. This recession slowed during late fall or early winter.

Prolonged upward or downward trends in these levels generally reflect long wet or dry periods. This point is illustrated by figure 10 where monthly mean lake stage for Cedar Lake is compared with monthly cumulative departure from normal precipitation at the nearby National Weather Service station at Chilton, Wis. Prolonged periods of below-normal precipitation are characterized by downward trends in the cumulative departure curve. Conversely, prolonged periods of above-normal precipitation are characterized by upward trends in the cumulative departure curve. Lake-level trends closely follow trends in the cumulative departure curve.

\section{WATER BUDGET}

A water budget quantifies water movement using the mass conservation principle. Mass conservation requires that changes in the volume of water in Cedar Lake during a given time period be equal to the difference between water gains and losses in the lake during that period. Water gains to Cedar Lake are precipitation on the lake surface, ground-water seepage to the lake, overland flow to the lake, and pumpage into the lake from the sanitary district well. Water losses are evaporation from the lake surface and seepage from the lake to the ground-water system.

\section{Budget equations}

A water budget for Cedar lake for a given time increment can be expressed in equation form as:

$$
\Delta S=P+I_{G}+I_{O}-E-O_{G}+Q
$$

where: $\Delta \mathrm{S}=$ change in lake stage, in inches;

$$
\begin{aligned}
& P=\text { precipitation on the lake surface, in inches; } \\
& I_{G}=\text { ground-water seepage to the lake, expressed as an equivalent } \\
& \text { depth of water on the lake surface, in inches; } \\
& I_{0}=\text { overland flow to the lake, expressed as an equivalent depth } \\
& \text { of water on the lake surface, in inches; } \\
& \mathrm{E}=\text { evaporation from the lake surface, in inches; } \\
& O_{G}=\text { seepage from the lake to the ground-water system, expressed } \\
& \text { as an equivalent depth of water on the lake surface, in } \\
& \text { inches; } \\
& Q=\text { pumpage into the lake from the nearby sanitary district well, } \\
& \text { expressed as an equivalent depth of water on the lake } \\
& \text { surface, in inches. }
\end{aligned}
$$


This equation was modified slightly to aid in water-budget computations. Parameters that could not be measured or computed directly from the data were grouped together as a residual term, $R$, and the water-budget equation was rewritten as:

$$
\Delta S=P-E+Q+R
$$

where: $\quad R=I_{G}+I_{O}-O_{G}$, expressed as an equivalent depth of water on the lake surface, in inches.

Monthly and annual water budgets based on equation 2 for the 3-year period, October 1, 1974, to September 30, 1977, and the estimated long-term water budget for Cedar Lake are given in table 3. The location of monitoring sités used in conjunction with measuring or estimating water-budget components are shown in figure 11. The period October 1 to September 30 of the succeeding year is defined as a water year. This yearly period is used for waterbudget computations.

\section{Parameter determination}

Lake stage was monitored continuously using a digital stage recorder. The average daily lake stage for the 3 years was $890.13 \mathrm{ft}$ or approximately $1.5 \mathrm{ft}$ above the mean lake stage from January 1946 to December 1976. The maximum daily lake stage during the 3 years was $891.23 \mathrm{ft}$ on May 16, 1976. This was the second highest lake stage ever recorded. A lake stage of $892.37 \mathrm{ft}$ was observed by DNR on May 20, 1929.

Precipitation was measured by a recording precipitation gage at the pumping well. Average precipitation at Cedar Lake during the 3 years was 29.71 in. per water year. Precipitation was slightly more than this 3-year average for water years 1975 and 1977. Precipitation for water year 1976 was $4 \mathrm{in}$. below this average. Long-term average yearly precipitation for the area, based on data from the National Weather Service stations at Chilton and Plymouth, Wis., (fig. 1) is approximately $30 \mathrm{in.}$

Daily evaporation from the lake surface was computed using empirical relationships involving air temperature, dewpoint temperature, wind velocity, and percent possible hours of sunshine. The computations were done with the aid of a digital computer using equations developed by Lamoreux (1962) but modified to use percent possible hours of sunshine data in place of solar radiation data. Sunshine data were converted to solar radiation data by use of a technique developed by Hamon and others (1954). Air temperature was measured at Cedar lake using a digital temperature recorder. Dewpoint temperature, wind velocity, and sunshine data were taken from National Weather Service records for Green Bay, Wis., approximately $40 \mathrm{mi}$ north of Cedar Lake. Computed evaporation for water year 1975 was approximately equivalent to the long-term average of 28 in. per year for the area (Kohler, 1959, pl. 2). Evaporation for both 1976 and 1977 water years was approximately 5 in. above the long-term average. Daily maximum temperatures averaging 20 to $4 \circ \mathrm{F}$ above normal and percent possible sunshine averaging 8 to 10 percent above normal for the 6-month period, April through September of 1976 and 1977, partly accounted for the increased evaporation during these years. 


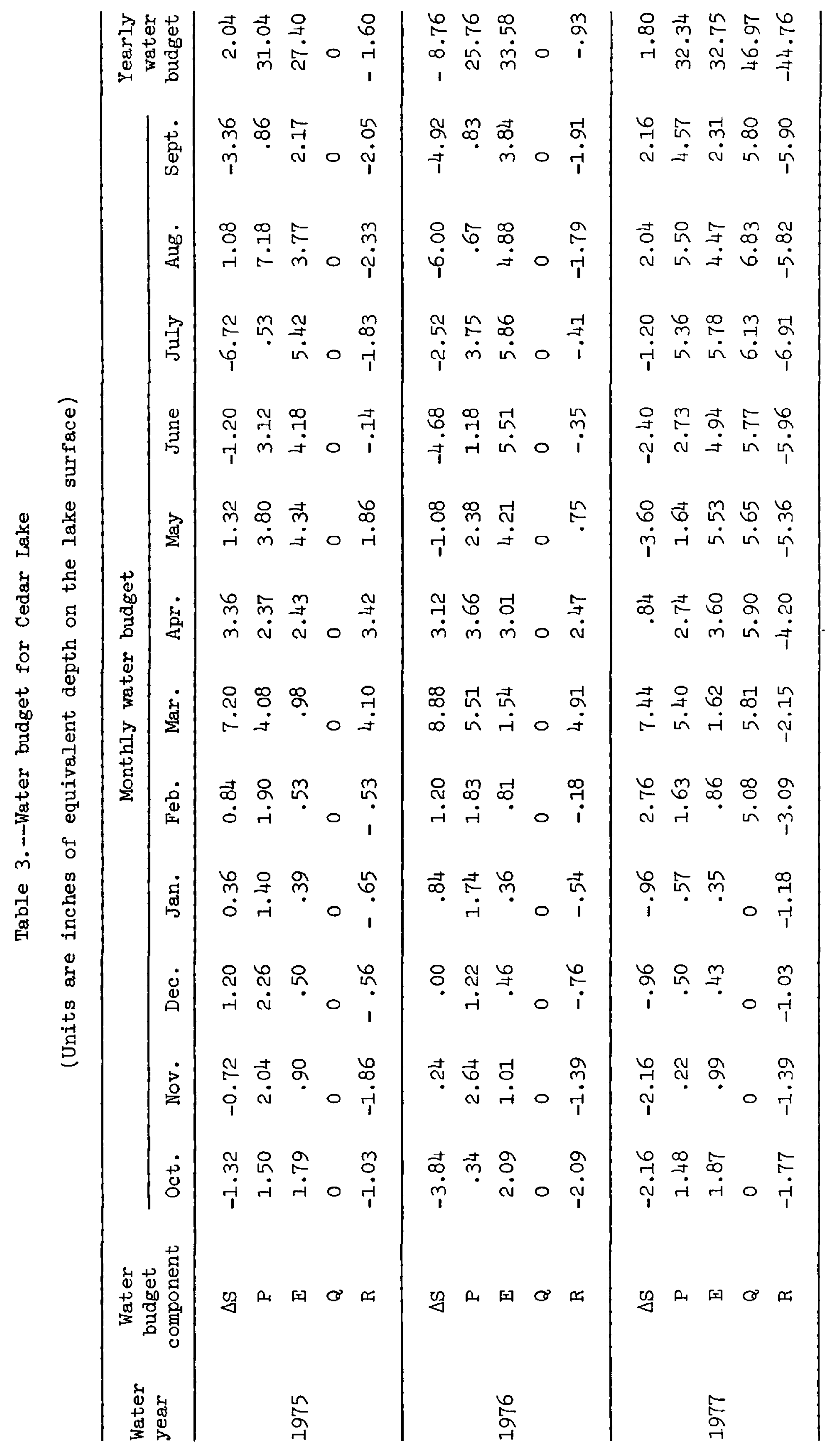


Analysis of residual term

Residual water gains or losses resulting from the combined effects of water seepage and overland flow were calculated by balancing equation 2 . The calculated greatest net monthly water gain to the lake resulting from these combined effects was 4.91 in. in March 1976. The calculated greatest net monthly water loss from the lake resulting from these same effects, but before pumping, was 2.33 in. in August 1975. This residual averaged a 4.92 in. per month loss during the pumping period.

Net ground-water exchange between the lake and the ground-water system averaged -16 in. per year for the 2 years before pumping. It varied between -0.5 to -1 in. per month during winter and between -2 to -2.5 in. per month during summer and fall. Overland flow was assumed to be negligible during December, January, and February of each water year that had no appreciable precipitation and during June through November of each water year that had no intense storms to arrive at monthly net ground-water seepages for these periods. Net ground-water seepage during spring months was assumed to average approximately the same as that during early summer months.

Ground-water seepage to the lake before pumping was estimated to be 10 percent that of seepage from the lake to the ground-water system. This calculation was based on ground-water gradients and areas of ground-water flow to and from the lake determined from water levels measured in the piezometers around the lake. Ground-water levels and flow areas during late October 1975 are shown in figure 12. This pattern was typical of ground-water conditions that existed during the study, but before pumping.

Ground-water seepage to the lake averaged 2 in. per year, and seepage from the lake to the ground-water system averaged 18 in. per year before pumping on the basis of the above analysis.

Overland flow to the lake, estimated using the residual term and the results of the seepage analysis, averaged approximately 15 in. per year before pumping. This is equivalent to an overland flow to the lake of 1 in. per year from the entire basin. Overland flow was greatest in March averaging 4 to $5 \mathrm{in}$. per month. It then declined to an average of 1 to 2 in. per month by June. Overland flow was generally minor or insignificant during other months.

\section{Other observations}

Ground-water seepage seems to be temperature dependent. Seepage from the lake to the ground-water system would decrease by 50 percent or more from late summer to midwinter each year, while the average ground-water level around the lake would decline in relation to the level of the lake. A gradient change of this nature would be expected to induce an increase in seepage from Cedar lake to the ground-water system if all other factors affecting flow remained constant. The discrepancy could be partly accounted 


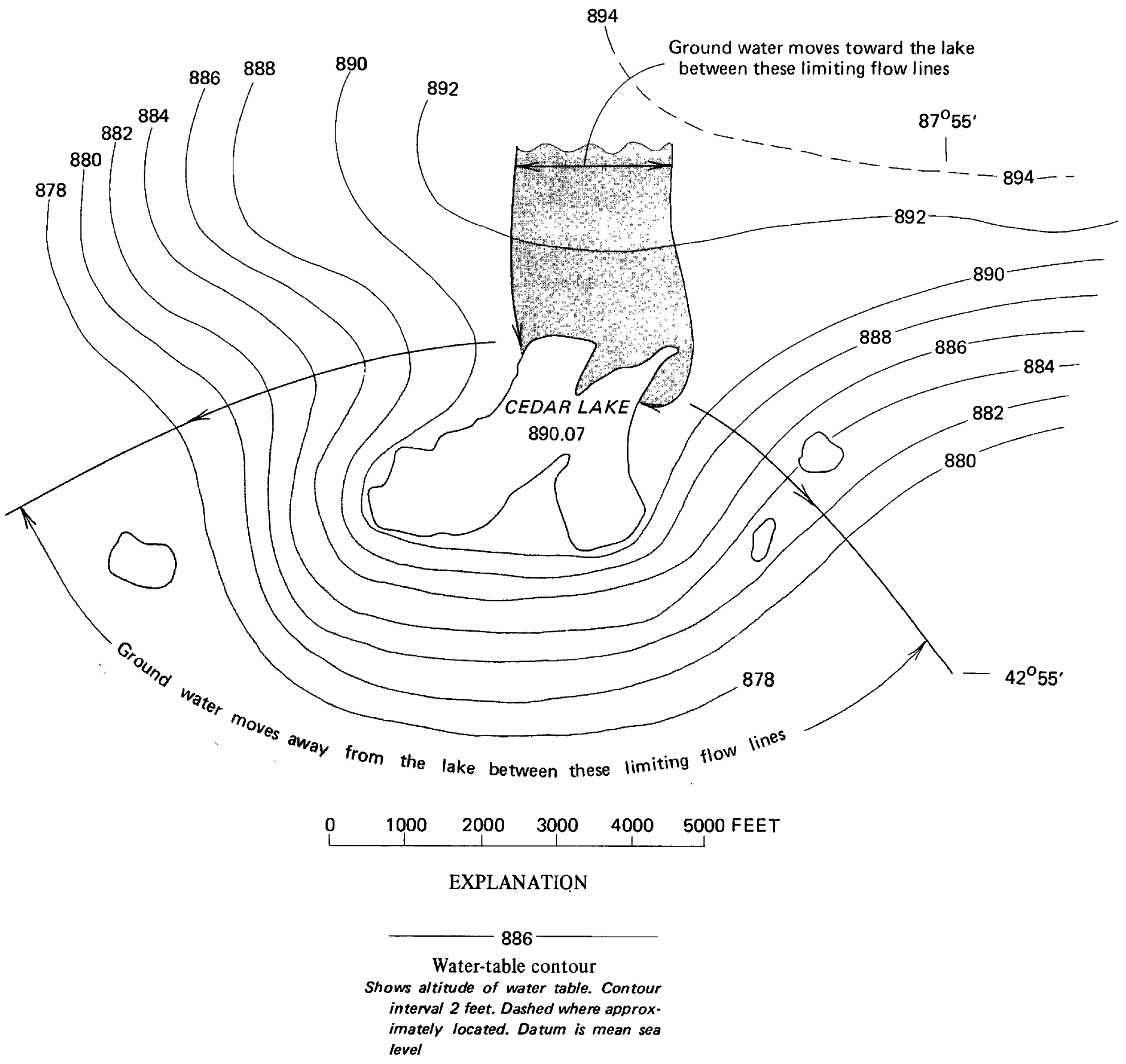

Figure 12. Water table and ground-water flow near Cedar Lake, October 28, 1975. 
for by changes in lake-water temperature. The water temperature at the lake bottom declined from $20^{\circ}$ to $2^{\circ} \mathrm{C}$ between late summer and midwinter. The change in water viscosity that accompanies this much temperature change is enough to reduce the flow of water from the lake to the ground-water system by approximately 40 percent.

The effects of climatic fluctuations on the various water-budget components are emphasized by the time increment used in the water-budget analysis. The monthly water budget emphasizes fluctuations in the various budget components caused by seasonal climatic differences. The yearly water budget masks monthly fluctuations and emphasizes fluctuations caused by cyclical variations in climatic conditions.

A long-term water budget for the lake without pumping reflects longterm climatic conditions. For this case, average water gains and losses are equal, and long-term changes in lake stage are zero. Long-term average water losses are residual losses and evaporation losses. The only longterm water gain is precipitation. Long-term evaporation averages 28 in. per year and long-term precipitation averages 30 in. per year for the area. Thus, long-term residual losses average 2 in. per year.

\section{RESPONSE TO HYDROLOGIC SYSTEM TO PUMPING GROUND WATER INTO CEDAR LAKE}

\section{BACKGROUND}

The sanitary district's high-capacity well near the northeast shore of the lake (fig. 11) was used for pumping water into the lake. The well is $600 \mathrm{ft}$ deep and is open only in the Niagaran dolomite. The upper $135 \mathrm{ft}$ was drilled in glacial drift. The remaining $465 \mathrm{ft}$ was drilled in the dolomite. The well was cased $142 \mathrm{ft}$.

The sanitary district well discharged water into Cedar Lake from February 1, 1977, to November 19, 1977. These dates were selected by area residents at ad hoc public meetings held by the sanitary district shortly before February 1 and November 19.

Parameters needed for monitoring hydrologic changes caused by the pumping were measured from February 1, 1977, to September 30, 1977. Water levels were measured in the pumping well and in piezometers $\mathrm{Mn} \mathrm{184,} \mathrm{185,}$ $186,187,188,189$, and 190 ( $\mathrm{fig} .11$ ) to define changes in ground-water levels caused by the pumping. Water-budget data for the lake were collected to define changes in lake stage that could be attributed to the pumping.

The monthly well discharge averaged $520 \mathrm{gal} / \mathrm{min}$ during the measurement period. It ranged between $590 \mathrm{gal} / \mathrm{min}$ for August and $488 \mathrm{gal} / \mathrm{min}$ for May.

\section{GROUND-WATER-LEVEL CHANGES NEAR CEDAR LAKE}

The water level in the pumping well declined approximately $25 \mathrm{ft}$ between February 1 and september 30. Twenty-one feet of this decline 
occurred during the first day and was caused by the pumping. The remaining $4 \mathrm{ft}$ of decline occurred over the rest of the 8-month period and resulted from general water-level changes in the area as well as pumping.

Pumping caused a water-level decline in the overlying glacial drift near the pumping well (fig. 13). The amount of decline was small and decreased with increasing distance from the well.

The response of the water level in the glacial drift to pumping from the Niagaran dolomite indicated a good hydraulic connection between these two geologic units. Water from the glacial drift began flowing toward the pumping well almost immediately after pumping began.

\section{WATER-LEVEL CHANGES IN CEDAR LAKE}

A volume of water equivalent to the amount for a 47-in. rise was pumped into Cedar Lake between February 1 and September 30. This volume of water amounts to 41 percent of the total volume of water in the lake at normal lake stage.

Between 42 to 44 in. of the water pumped during this period was recycled from the lake to the well or otherwise lost as seepage from the lake. This loss totaled approximately 90 percent of the water pumped. Only 3 to $5 \mathrm{in.}$ of pumped water was effective in maintaining the lake level, with pumping being most effective during the first few weeks.

The lake level rose 12 in. between February 1 and April 5 (fig. 14). This rise was in response to overland flow to the lake, precipitation on the lake surface, and pumpage of ground water into the lake. Ground-water pumpage into the lake was responsible for the 2-in. rise in lake level between February 1 and February 23. There was no precipitation or runoff during this time. Between February 23 and April 5, the lake rose an additional 10 in. Eight to $9 \mathrm{in.} \mathrm{of} \mathrm{this} \mathrm{rise} \mathrm{was} \mathrm{attributable} \mathrm{to} \mathrm{precipitation} \mathrm{on}$ the lake surface and overland flow to the lake of snowmelt and precipitation. Pumping accounted for the remaining 1 to 2 in.

The lake level declined 4 in. between April 5 and September 30. The decline occurred because evaporation and seepage from the lake exceeded precipitation and overland flow during this period. Pumping had little effect ( 0 to 1 in.) in maintaining the lake level during this time because almost all of the pumped water was being recycled or otherwise lost through seepage from the lake.

Induced seepage losses caused by pumping were significant even during early weeks of pumping. The 2-in. rise in the lake level attributable to pumping during the first 3 weeks was in response to pumping more than 4 in. of water into the lake. Thus, an average of more than 50 percent of the pumped water was recycled or otherwise lost through seepage from the lake bottom even during this early period. 


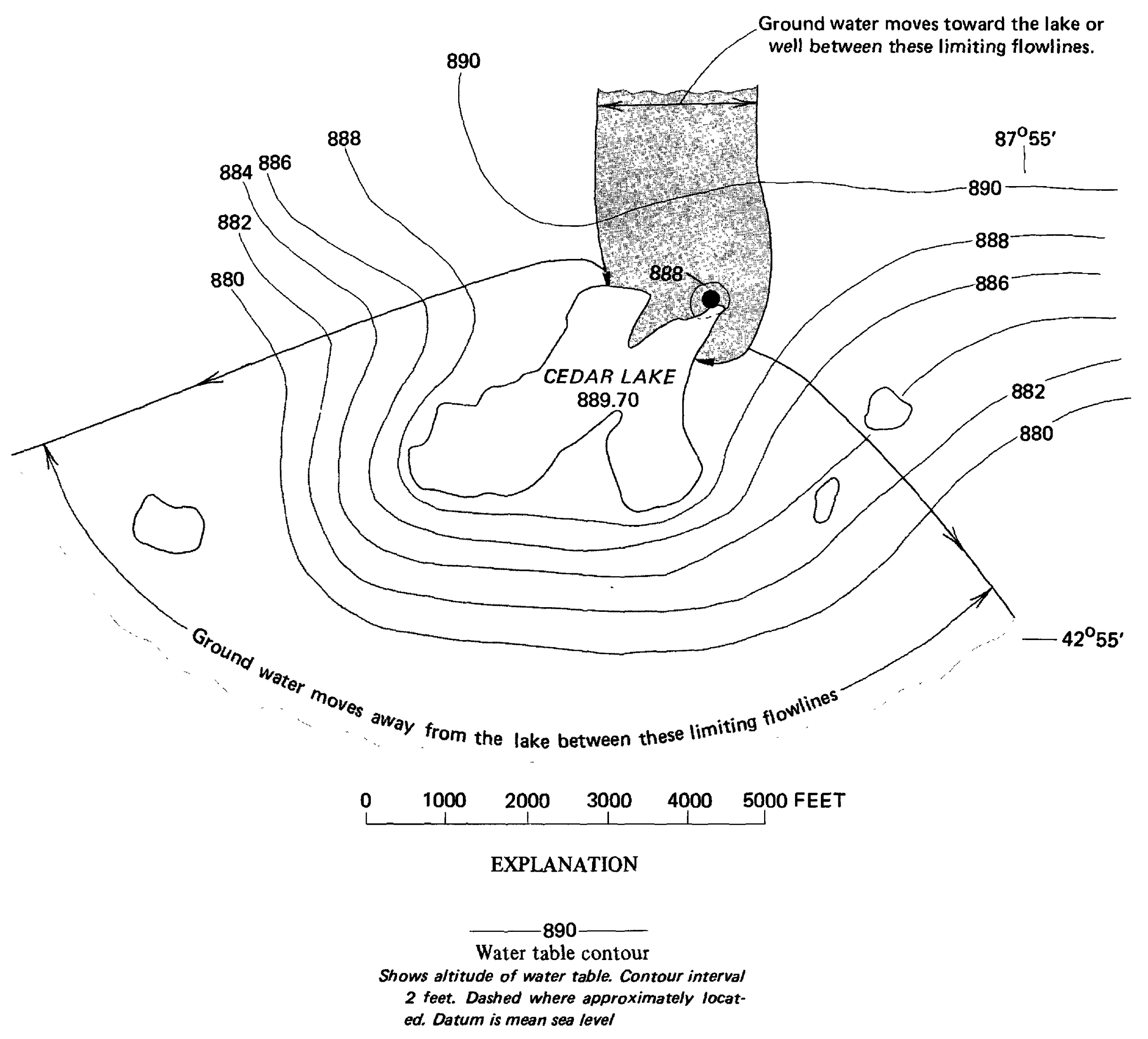

Pumping well

Figure 13. Water table and ground-water flow near Cedar Lake, May 25, 1977. 


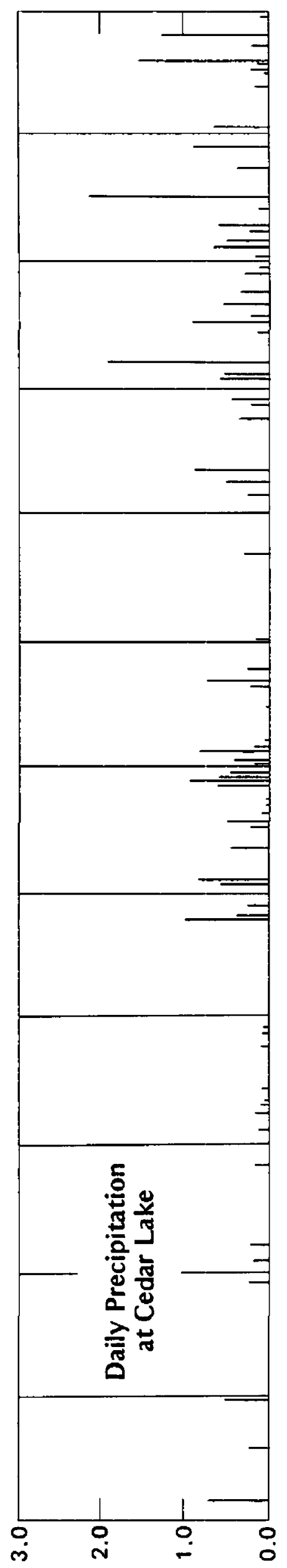

S $\exists$ HONI NI 'NOIL $\forall \perp I d I 0 \exists y d$
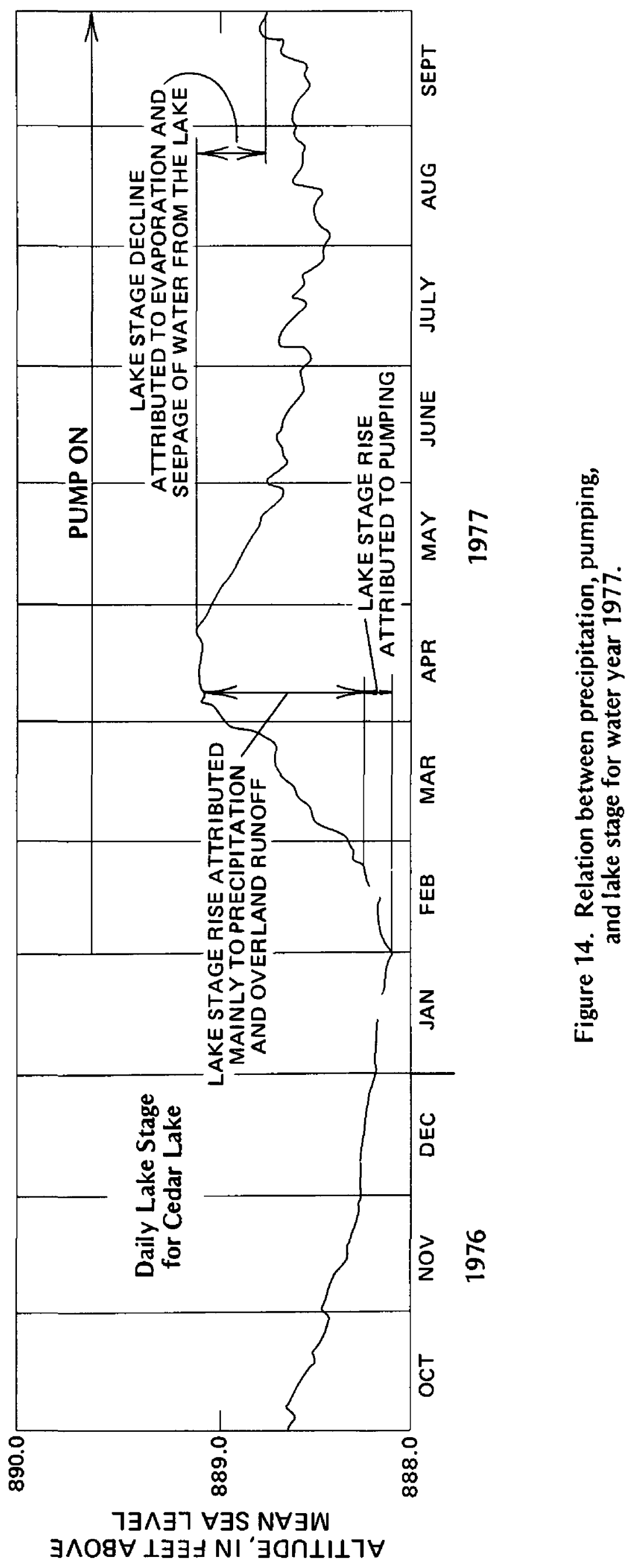


\section{WATER QUALITY AND BIOLOGICAL CONSIDERATIONS}

Physical and chemical processes in Cedar Lake interact to provide the habitat for the lake's biological community. Selected physical and chemical properties of the lake were monitored to identify water quality during the study .

Measured physical and chemical properties of the pumped ground water included temperature, total nitrogen concentration, and total phosphorus concentration. These properties were measured at the point of well discharge into the lake. Ground-water temperature remained uniform at $9^{\circ}$ to $10^{\circ} \mathrm{C}$ during pumping. Total nitrogen concentration averaged $0.5 \mathrm{mg} / \mathrm{L}$. It declined from $1,0 \mathrm{mg} / \mathrm{L}$ in February to $0.3 \mathrm{mg} / \mathrm{L}$ in September. Total phosphorus concentration averaged $0.01 \mathrm{mg} / \mathrm{L}$. It declined from $0.02 \mathrm{mg} / \mathrm{L}$ in February to $0.00 \mathrm{mg} / \mathrm{L}$ by May.

Measured physical and chemical properties of the lake water included temperature distribution, dissolved-oxygen concentration, total nitrogen concentration, and total phosphorus concentration. These water properties were measured at sites $A$ and $B$ in Cedar Lake ( $f i g .11$ ).

The temperature distribution and dissolved-oxygen concentration of lake water were measured at $1-\mathrm{m}$ intervals between the lake surface and bottom. These parameters changed with depth and season but were areally uniform. Water in the lake circulates in the spring and again in autumn. During these times, temperature and dissolved oxygen are uniform throughout the depth of the lake. The spring circulation period began at the time of breakup of ice cover, generally early or mid-April, and lasted about I month. Lake temperature warmed from $4{ }^{\circ} \mathrm{C}$ to approximately $10^{\circ} \mathrm{C}$ during this period, and the dissolved-oxygen concentration of the water rose from 5 to $8 \mathrm{mg} / \mathrm{L}$ to approximately $10 \mathrm{mg} / \mathrm{L}$. Vertical temperature and dissolvedoxygen gradients developed in the lake during the time between the spring and autumn circulation periods. These gradients became more pronounced near the bottom of the lake as summer progressed. The autumn circulation period began in August and lasted until the lake froze over in December. During this time the water cooled from approximately $25^{\circ}$ to $2^{\circ} \mathrm{C}$, and the dissolved-oxygen concentration rose from 7 to $9 \mathrm{mg} / \mathrm{L}$ to 12 to $13 \mathrm{mg} / \mathrm{L}$. During the ice cover period, a weak vertical dissolved-oxygen gradient and a slight inverse vertical temperature gradient developed. The dissolvedoxygen concentration of the water was slowly depleted during this time, reaching a low of $8 \mathrm{mg} / \mathrm{I}$ near the surface of the lake and $5 \mathrm{mg} / \mathrm{L}$ near the bottom of the lake just before spring breakup of ice cover, while the water temperature increased slightly to $4^{\circ} \mathrm{C}$. Composited measurements from sites $\mathrm{A}$ and $B$ for 1975-77 illustrate the general progression of the temperature and dissolved-oxygen cycles in the lake (figs. 15 and 16).

Temperature and dissolved-oxygen cycles before and during pumping have the same general characteristics. There was no evidence of ground-water stratification or other alterations in these cycles that could be directly attributed to the pumping. The early breakup of ice cover in 1977 was due to above-normal air temperatures during late March. 


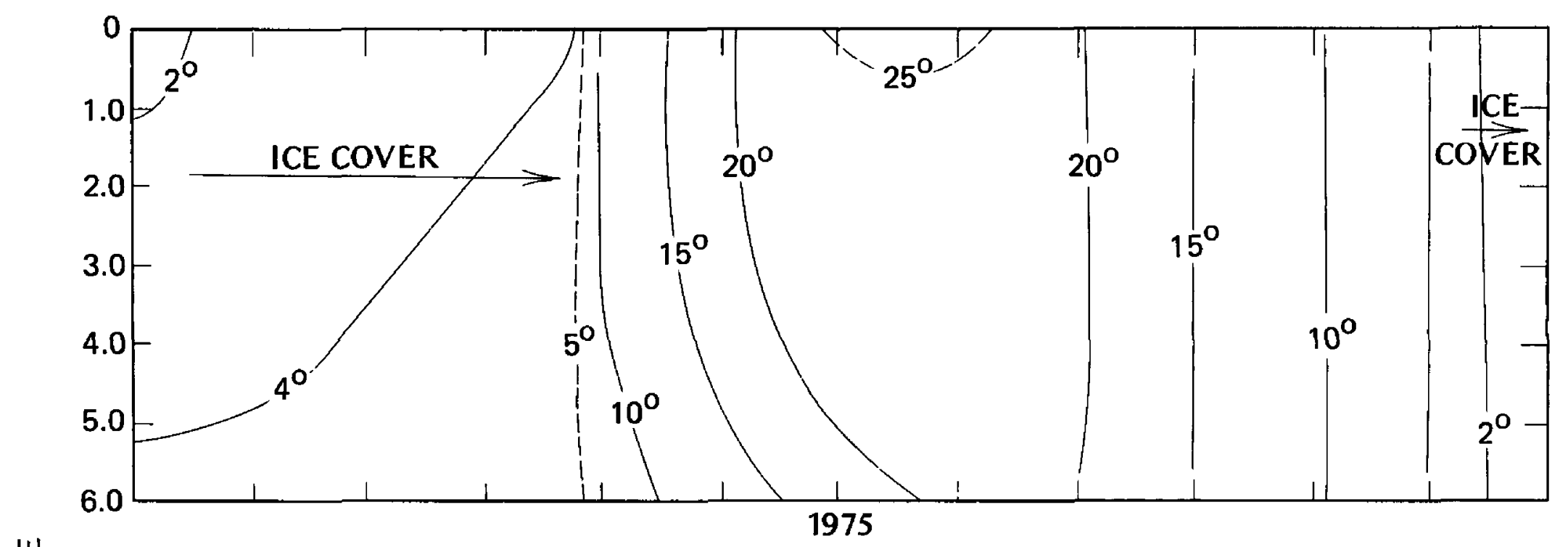

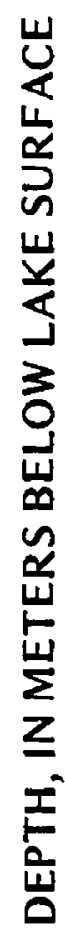

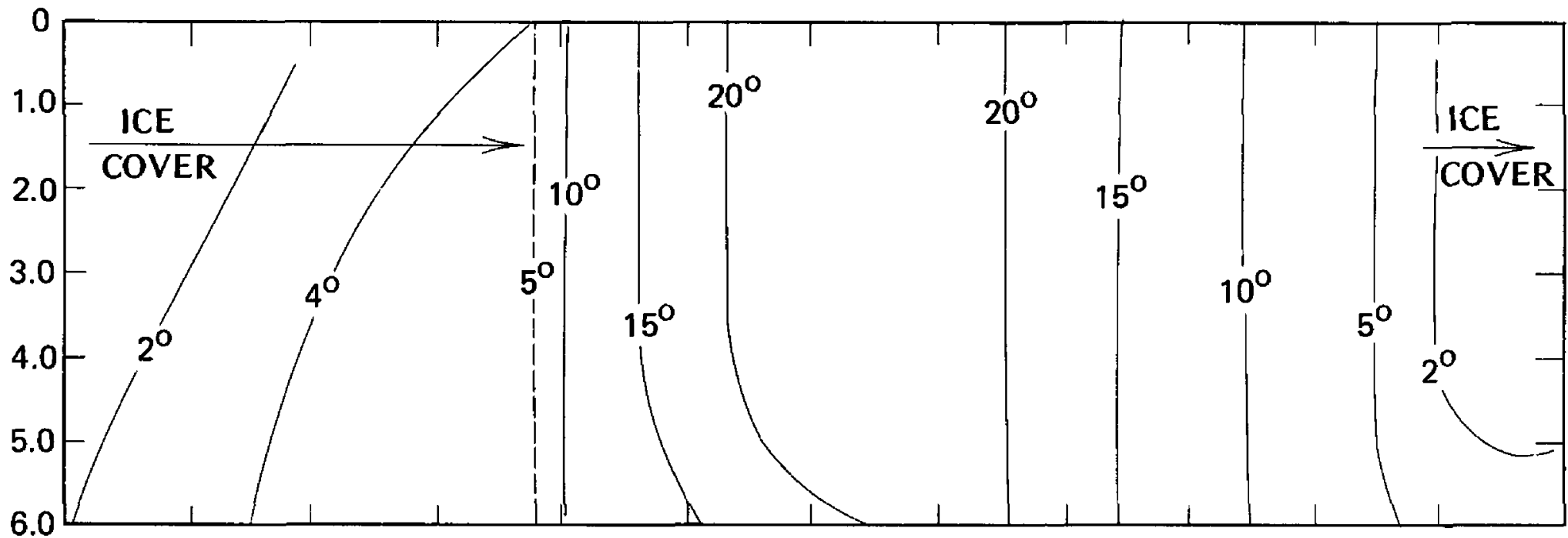

1976

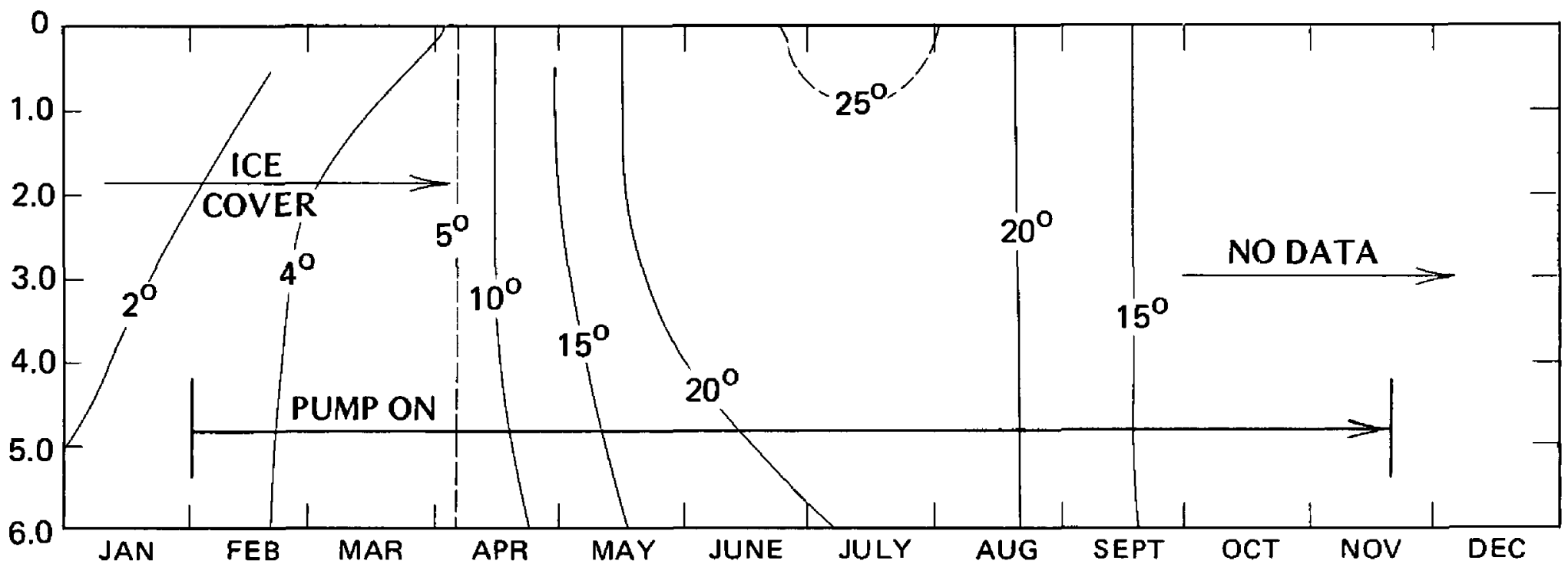

1977

\section{EXPLANATION}

$10^{\circ}$

Line of equal water temperature

Interval $5^{\circ} \mathrm{C}$, with supplemental lines at

$2^{\circ} \mathrm{C}$ and $4^{\circ} \mathrm{C}$. Dashed where approximated

Figure 15. Observed temperature distribution in Cedar Lake, 1975-77. 


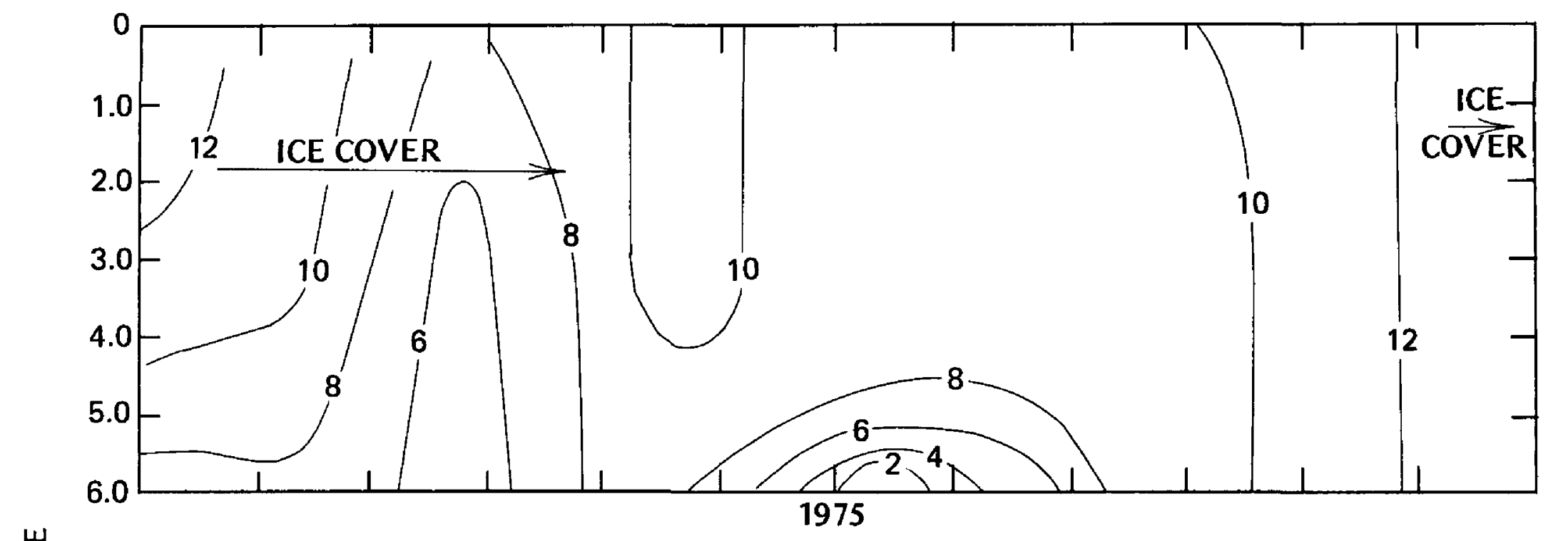

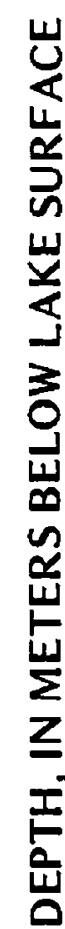

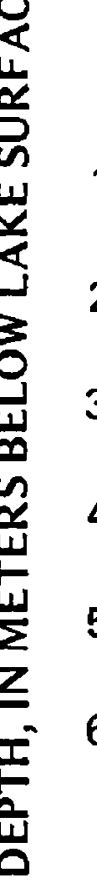

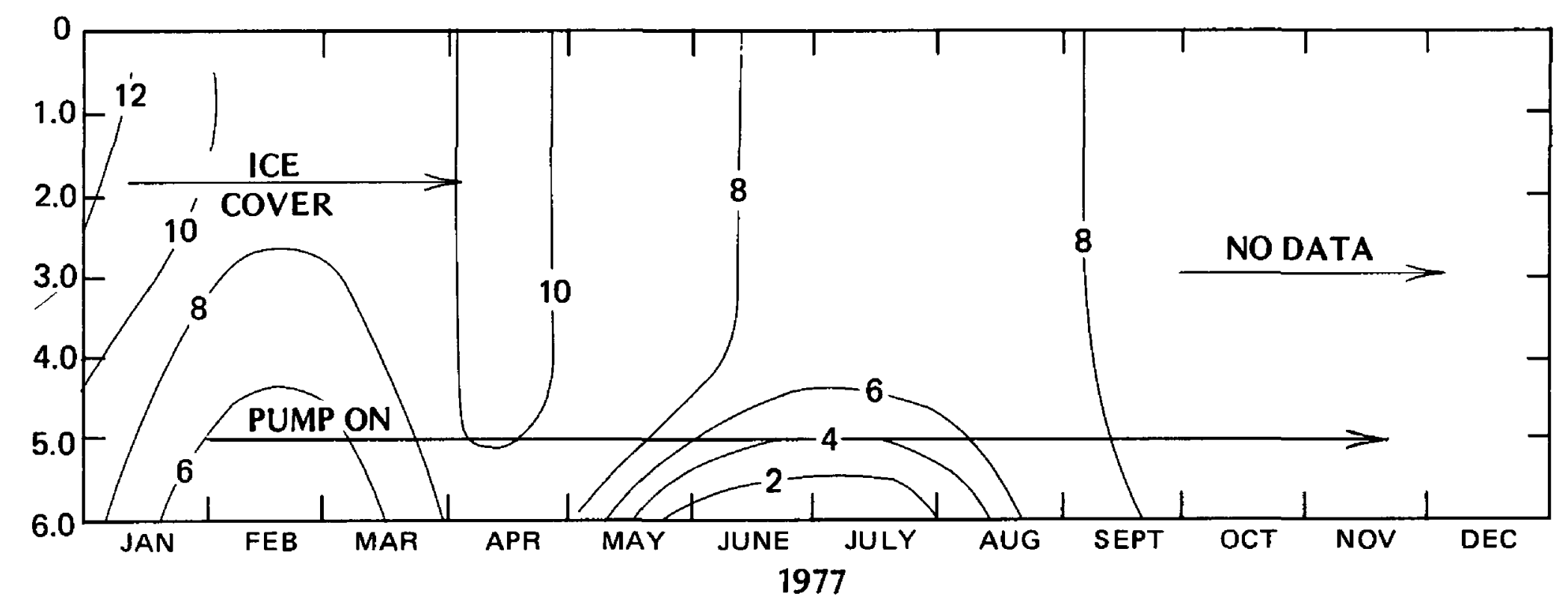

\section{EXPLANATION}

10

Line of equal dissolved oxygen concentration

Interval 2 milligrams per liter

Figure 16. Observed dissolved-oxygen distribution in Cedar Lake, 1975-77. 
Nitrogen and phosphorus concentrations in lake water were measured at $1.5 \mathrm{~m}$ and $4.5 \mathrm{~m}$ below the surface of the lake. These elements are important nutrients for plant growth and are essential to the maintenance of the biological community of the lake. Measured total nitrogen concentration in the water varied between 0.4 and $1.9 \mathrm{mg} / \mathrm{L}$. Measured total phosphorus concentration varied between 0.00 and $0.06 \mathrm{mg} / \mathrm{L}$. There was little seasonal
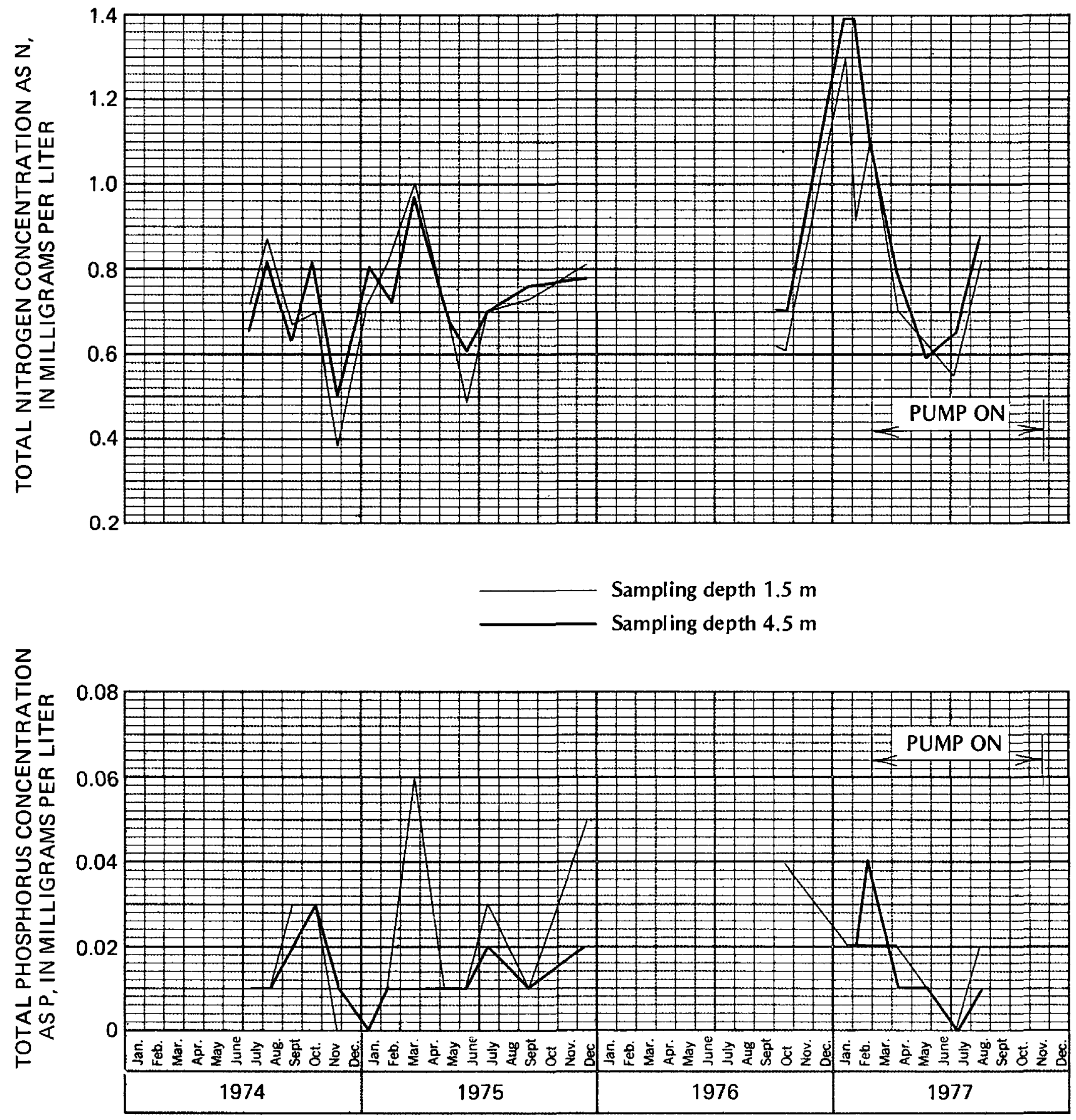

Figure 17. Observed total nitrogen and total phosphorus concentrations of water in Cedar Lake at site A. 
change in these elements. Nitrogen and phosphorus measurements at site A are shown in figure 17 to illustrate variations in concentration of these constituents during the study.

The total nitrogen and total phosphorus concentrations in the lake water were apparently not affected by the pumping. A statistical comparison of combined data for sites $A$ and $B$ before and during pumping suggested that there were no significant differences in the nitrogen or phosphorus concentrations of the lake water during these two periods. Also, variations in total nitrogen and total phosphorus concentrations of the lake water between sites $A$ and $B$ during pumping were not statistically significant.

A lack of change in nitrogen and total phosphorus concentrations of the lake water during pumping was not surprising, as the contents of these elements in both the lake water and ground water pumped into the lake are not appreciably different.

The concentration and composition of phytoplankton in the water are indicators of the lake's biological activity. Phytoplankton are the base upon which the food chain for higher life forms in the lake depends.

The phytoplankton community was sampled periodically at a depth of $1.5 \mathrm{~m}$ below lake surface at sites $A$ and $B$. The phytoplankton population was found to be small during winter months, generally between 100 and $1,000 \mathrm{cells} / \mathrm{ml}$. These phytoplankton were composed of euglenoids, diatoms, green algae, and blue-green algae. During August, September, and October, the phytoplankton population increased to 50,000 to 100,000 cells $/ \mathrm{mI}$. Blue-green algae dominated the phytoplankton community during these times. The measured phytoplankton population and composition at site $A$ is given in table 4 to illustrate observed variations in this community. The exceedingly high cell counts for the blue-green algae during August, September, and October may be misleading. The dominant organisms in each case are extremely small colonial algae. The analytical methods that were used in their enumeration enhanced their numbers out of proportion to their ecological importance.

There are no readily identifiable changes in seasonal trends in concentration and composition of the phytoplankton community resulting from pumping ground water into the lake. Seasonal variations in phytoplankton before pumping appeared similar to seasonal variations experienced during pumping.

A lack of change in concentration and composition of the phytoplankton community during pumping was not surprising. The availability of nitrogen and phosphorus to the biological community are dominating influences on the biological community, and the contents of these elements in both the lake water and ground water pumped into the lake are essentially the same. 


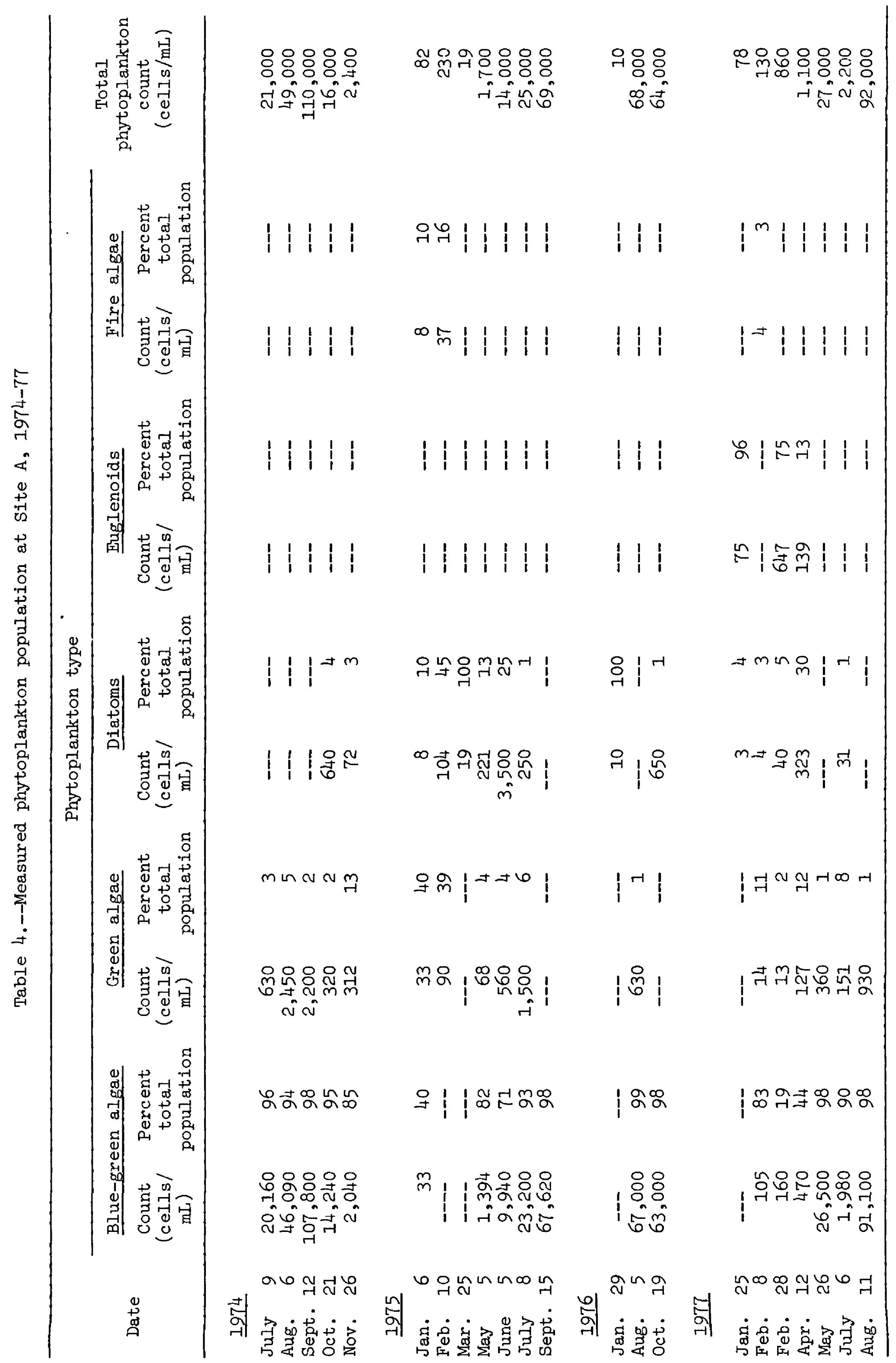




\section{SUMMARY AND CONCLUSIONS}

Cedar Lake, a kettle lake with no surface inlet or outlet, was studied to evaluate the feasibility of maintaining water levels of lakes in the glaciated kettle moraine area of eastern Wisconsin by pumping ground water into them. The general hydrogeology of the area around the lake was defined, and the hydrology of the lake was studied in detail.

A volume of water equivalent to that needed to raise the lake level 47 in. was pumped into the lake from a well in the shallow aquifer between February 1 and September 30, 1977. Pumpage to the lake was the dominant inflow during this time. Forty-two to 44 in., or a volume equivalent to approximately 90 percent of the pumped water, was recycled from the lake to the well or otherwise lost as seepage from the lake during the same time. This loss was the dominant outflow. Only 3 to 5 in. of pumped water was effective in maintaining the lake level.

Precipitation was the dominant inflow, averaging $28.4 \mathrm{in}$. per year, and evaporation was the dominant outflow, averaging 30.5 in. per year before pumping. Overland flow to the lake averaged $15 \mathrm{in}$. per year. Water exchange between the lake and ground-water system was composed of 2 in. per year of ground-water seepage to the lake and $18 \mathrm{in.}$ per year of seepage from the lake to the ground-water system.

There were no changes in measured physical and chemical properties of the lake water that could be directly attributed to pumping. Either changes that were occurring in the lake as a result of the pumping had not extended to the area of the monitoring sites or the differences in measured properties of the lake water and ground water were not great enough to cause changes in these properties within the lake.

The phytoplankton community also did not appear to be affected by the addition of ground water to the lake. Seasonal variations in the phytoplankton population before pumping appeared similar to seasonal variations experienced during pumping.

\section{REFERENCES CITED}

Hamon, R. W., Weiss, L. L., and Wilson, W. T., 1954, Insolation as an emperical function of daily sunshine duration: Monthly Weather Review, vol. 82, no. 6 .

Kohler, M. A., Nordenson, T. J., and Baker, D. R., 1959, Evaporation maps for the United States: U.S. Weather Bureau Technical Paper No. 37, $13 \mathrm{p}$.

Lamoreaux, W. W., 1962, Modern evaporation formulae adapted to computer use: Monthly Weather Review, vol. 90, no. 1. 
Ryling, R. W., 1961, A preliminary study of the distribution of saline water in the bedrock aquifers of eastern Wisconsin: Wisconsin Geological and Natural History Survey Information Circular No. 5, 23 .

Skinner, E. L., and Borman, R. G., 1973, Water resources of Wisconsin--Lake Michigan basin: U.S. Geological Survey Hydrologic Investigations Atlas HA-432.

Weidman, Samuel, and Schultz, A. R., 1915, The underground and surfacewater supplies of Wisconsin: Wisconsin Geological and Natural History Survey Bulletin 35, $664 \mathrm{p}$. 


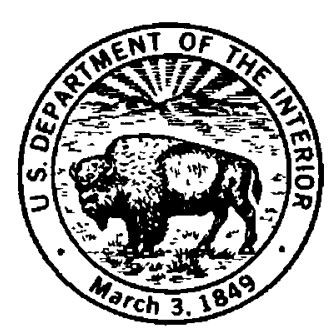

